1

4

15

16

17

18

19

20

21

22

\title{
Quantitative fluorescence lifetime imaging uncovers a novel role for KCC2 chloride transport in dendritic microdomains
}

Nicholas L. Weilinger*1, Jeffrey M. LeDue ${ }^{1}$, Kristopher T. Kahle ${ }^{2}$ and Brian A. MacVicar*1

(1)

\section{Affiliations:}

(1)
1) Djavad Mowafaghian Centre for Brain Health, University of British Columbia, Vancouver, V6T 1Z3, Canada
2) Departments of Neurosurgery, Pediatrics, and Cellular \& Molecular Physiology, Yale School of Medicine, Yale University, New Haven, CT, 06520, USA

*Correspondence: nicholas.weilinger@ubc.ca and bmacvicar@brain.ubc.ca

5

Keywords: KCC2, Chloride, FLIM, NKCC1, MQAE, swelling, cytotoxic edema, dendrite, blebbing \section{8}


Intracellular chloride ion $\left(\left[\mathrm{Cl}^{-}\right]_{\mathrm{i}}\right)$ homeostasis is critical for synaptic neurotransmission yet variations in subcellular domains are poorly understood owing to difficulties in obtaining quantitative, high-resolution measurements of dendritic $\left[\mathrm{Cl}^{-}\right]$i. We combined whole-cell patch clamp electrophysiology with simultaneous fluorescence lifetime imaging (FLIM) of the $\mathrm{Cl}^{-}$dye MQAE to quantitatively map dendritic $\mathrm{Cl}^{-}$levels in normal or pathological conditions. FLIM-based $\left[\mathrm{Cl}^{-}\right]_{\mathrm{i}}$ estimates were corroborated by RubiGABA uncaging to measured $\mathrm{E}_{\mathrm{GABA}}$. Low baseline $\left[\mathrm{Cl}^{-}\right]_{\mathrm{i}}$ in dendrites required $\mathrm{Cl}^{-}$efflux via the $\mathrm{K}^{+}-\mathrm{Cl}^{-}$ cotransporter KCC2 (SLC12A5). In contrast, pathological NMDA application generated spatially heterogeneous subdomains of high $\left[\mathrm{Cl}^{-}\right]_{\mathrm{i}}$ that created dendritic blebs, a signature of ischemic stroke. These discrete regions of high $\left[\mathrm{Cl}^{-}\right]_{\mathrm{i}}$ were caused by reversed $\mathrm{KCC} 2$ transport. Therefore monitoring $\left[\mathrm{Cl}^{-}\right.$ ] microdomains with a new high resolution FLIM-based technique identified novel roles for KCC2dependent chloride transport to generate dendritic microdomains with implications for disease.

\section{Introduction} concentration $\left(\left[\mathrm{Cl}^{-}\right]_{\mathrm{i}}\right.$, which is critical for early brain development, setting membrane excitability, and cell volume regulation (Doyon et al., 2016; Kaila et al., 2014; Rungta et al., 2015). In mature nerve cells, low $\left[\mathrm{Cl}^{-}\right]_{\mathrm{i}}$ is maintained by $\mathrm{K}^{+}-\mathrm{Cl}^{-}$cotransporter $(\mathrm{KCC} 2)$-dependent extrusion to set gamma aminobutyric acid (GABA)ergic inhibitory tone (Cordero-Erausquin et al., 2005; Kahle et al., 2013; Staley and Proctor, 1999). KCC2 is expressed throughout the dendritic arbor in hippocampal and cortical pyramidal neurons (Gauvain et al., 2011; Gulyas et al., 2001) and is highly expressed in synaptic regions in close proximity to N-methyl-D-aspartate (NMDA), GABA, and $\alpha$-amino-3-hydroxy-5-methyl-4-isoxazolepropionic acid (AMPA) 
50 ionic plasticity (Chevy et al., 2015; Doyon et al., 2016; Garand et al., 2019; Gauvain et al.,

51 2011). It is becoming clear that $\left[\mathrm{Cl}^{-}\right]_{\mathrm{i}}$ heterogeneity in neuronal subdomains is a key determinant

52 of regional neurotransmission [(Barker and Ransom, 1978; Berglund et al., 2006; Glykys et al.,

53 2014; Khirug et al., 2008; Kuner and Augustine, 2000), but also that local perturbations in $\left[\mathrm{Cl}^{-}\right]_{\mathrm{i}}$

54 may underlie synaptic dysfunction. For instance, KCC2 dysregulation has been implicated in

55 multiple neurological disorders that involve synaptodendritic disinhibition, including epilepsy, neuropathic pain, schizophrenia, and autism (Cohen et al., 2002; Coull et al., 2003; Hyde et al.,

57 2011; Steffensen et al., 2015; Tao et al., 2012). However, the spatial distribution and magnitude of dendritic $\left[\mathrm{Cl}^{-}\right]_{\mathrm{i}}$ changes in these diseases are poorly understood due to a lack of quantitative imaging of $\left[\mathrm{Cl}^{-}\right]_{\mathrm{i}}$ dynamics at the subcellular level.

64 proteins like Clomeleons (Berglund et al., 2006; Grimley et al., 2013; Kuner and Augustine,

65 2000) and $\mathrm{Cl}^{-} / \mathrm{H}^{+}$sensors (Mukhtarov et al., 2013; Sulis Sato et al., 2017) use ratiometric

66 intensity emissions that are marred by divergent light scattering that is wavelength-, tissue depth-

67 , and age-dependent (Oheim et al., 2001). These probes are also sensitive to $\mathrm{pH}$ (Arosio et al., 68 2007; Tsien, 1998), which is problematic given the interrelationship between $\mathrm{Cl}^{-}$and $\mathrm{HCO}_{3}^{-}$

69 cotransport (Kaila, 1994) and their joint permeabilities through many $\mathrm{Cl}^{-}$channels (Bormann et al., 1987; Jun et al., 2016). 
73 FLIM is insensitive to changes in dye concentration, light scattering, and photobleaching (Chen

74 et al., 2013; Lloyd et al., 2010), making it ideal for quantifying $\left[\mathrm{Cl}^{-}\right]$i. The $\mathrm{Cl}^{-}$sensor N-

75 (ethoxycarbonylmethyl)-6-methoxyquinolinium bromide (MQAE) is suitable for FLIM with a

76 broad dynamic range of lifetimes and is insensitive to $\mathrm{pH}$ (Gensch et al., 2015; Kaneko et al.,

77 2002). Bulk-loaded MQAE has been used for quantitative $\mathrm{Cl}^{-}$imaging in situ in Bergmann glia,

78 dorsal root ganglion- and somatosensory neurons (Funk et al., 2008; Gilbert et al., 2007; Untiet

79 et al., 2017), and in large dendritic knobs of the vomeronasal organ (Kaneko et al., 2004; Untiet

80 et al., 2016). However, neurons bulk-loaded with MQAE have poor signal-to-noise over background staining, making it difficult to measure $\left[\mathrm{Cl}^{-}\right]_{\mathrm{i}}$ with synaptic resolution. electrophysiology to measure dynamic variations in dendritic $\left[\mathrm{Cl}^{-}\right]_{\mathrm{i}}$ and the spatial distributions of these changes under both physiological and pathological conditions. We show MQAE-FLIM can accurately quantify $\left[\mathrm{Cl}^{-}\right]_{\mathrm{i}}$ subdomains in dendrites, and that basal $\left[\mathrm{Cl}^{-}\right]_{\mathrm{i}}$ is maintained even when experimentally challenged with elevated $\mathrm{Cl}^{-}$loads. Using MQAE-FLIM, we quantified the

87 relative contributions of $\mathrm{KCC} 2$ and $\mathrm{NKCC} 1$ in setting regional $\mathrm{Cl}^{-}$electrochemical gradients, which we corroborated using Rubi-GABA uncaging to calculate $\mathrm{E}_{\mathrm{GABA}}$ (Rial Verde et al., 2008). Lastly, we demonstrate that NMDA can generate localized dendritic microdomains with regions of remarkably high and persistent dendritic $\left[\mathrm{Cl}^{-}\right]_{i}$ gradients. The formation of dendritic microdomains leads to the appearance of dendritic varicosities ("blebbing”) a hallmark of

92 dendritic pathology. Remarkably, bleb formation was prevented by furosemide, indicating 93 localized $\mathrm{Cl}^{-}$loading was due to reversed $\mathrm{K}^{+} / \mathrm{Cl}^{-}$transport. Together, our work highlights the 94 advantages of MQAE-FLIM to measure $\left[\mathrm{Cl}^{-}\right]_{\mathrm{i}}$ shifts with sub-micrometer resolution that would 95 be otherwise undetectable using intensity imaging or electrophysiology alone. Additionally, we 
have identified a novel role for $\mathrm{KCC} 2$ in dendritic microdomain $\mathrm{Cl}^{-}$homeostasis that critically impacts neuronal structure and function.

\section{Results}

\section{MQAE-FLIM calibrations for determination of $\left[\mathrm{Cl}^{-}\right]_{\mathbf{i}}$}

As a first step we determined the reliability of MQAE-FLIM to report $\left[\mathrm{Cl}^{-}\right]_{\mathrm{i}}$ by calibrating the dye in situ (in bulk-loaded cells) and in vitro (in recording solution in sealed pipettes) by time-correlated single-photon counting using 2-photon microscopy (Fig 1a). In situ calibrations were conducted in acute brain slices bulk-loaded with MQAE using nigericin and tributyltin to equilibrate $\left[\mathrm{Cl}^{-}\right]_{\mathrm{i}}=\left[\mathrm{Cl}^{-}\right]_{\mathrm{o}}$ across neuronal membranes (Gensch et al., 2015;

Kovalchuk and Garaschuk, 2012). We then measured MQAE-FLIM lifetimes corresponding to various $\mathrm{Cl}^{-}$concentrations (henceforth $M Q A E-\left[\mathrm{Cl}^{-}\right]$i, Fig 1b,c) in parallel to intensity changes. Bulk-loaded MQAE intensity decreased significantly in response to increasing $\left[\mathrm{Cl}^{-}\right]_{\mathrm{o}}$ but we also observed progressive decline over time due to a combination of dye loss and photobleaching (Fig 1a,c). Indeed, intensity changes did not reverse in $0\left[\mathrm{Cl}^{-}\right]_{\mathrm{o}}$ to wash out $\mathrm{Cl}^{-}$(Fig 1d). In contrast, the MQAE-FLIM channel revealed discrete lifetime changes in response to increasing $\left[\mathrm{Cl}^{-}\right]_{\mathrm{o}}$ that fully recovered in $0\left[\mathrm{Cl}^{-}\right]_{\mathrm{o}}$ washout despite the reduction in intensity signal (Fig 1d,e), highlighting the advantage and utility of FLIM in overcoming intensity artifacts arising from changes in dye concentration.

To combine MQAE-FLIM with whole-cell patch clamp, we conducted an additional in vitro calibration to complement and compare with the bulk-loaded in situ calibration. Whole cell 
117 loading provided improved signal to noise in dendritic compartments but it was important to

118 calibrate MQAE in the electrode solution that included HEPES and gluconate (Kaneko et al.,

119 2002). MQAE was dissolved in a K-gluconate recording solution with varied $\mathrm{Cl}^{-}$concentrations,

120 and MQAE-FLIM readouts were measured in sealed, temperature-controlled pipettes. $\mathrm{Cl}^{-}$-

121 dependent MQAE lifetimes varied over a broad dynamic range, from $\sim 4.1 \mathrm{~ns}$ to $\sim 1.2 \mathrm{~ns}$ when

$122\left[\mathrm{Cl}^{-}\right]_{\text {pipette }}$ was increased from $2.5 \mathrm{mM}$ to $110 \mathrm{mM}$, respectively (Fig $1 \mathrm{f}-\mathrm{h}$ ). The calibration data

123 were well-fit $\left(\mathrm{R}^{2}=0.992\right)$ to a single exponential decay curve with a calculated $K_{d}=23.78 \mathrm{mM}$

$124\left[\mathrm{Cl}^{-}\right]$that should be suitable to capture physiological to pathological variations in $\left[\mathrm{Cl}^{-}\right]_{\mathrm{i}}(\mathrm{Fig}$ 1h).

125 The reciprocal of the dataset from Fig $1 \mathrm{~h}$ correlated with a linear regression analysis (Fig 1i),

126 confirming that MQAE works through collisional $\mathrm{Cl}^{-}$quenching and therefore should not buffer

$127 \mathrm{Cl}^{-}$in solution (Verkman et al., 1989). As expected, the $\mathrm{Cl}^{-}$sensitivity of MQAE differed in in

128 situ and in vitro calibration environments (Stern-Volmer constants, $\mathrm{K}_{\mathrm{SV}}=6.53 \mathrm{M}^{-1}$ and 20.19 $\mathrm{M}^{-}$

$129{ }^{1}$, respectively, Fig $1 \mathrm{j}$ ), and the coefficient of variance was significantly lower in the in vitro

130 setting (Fig 1k). 

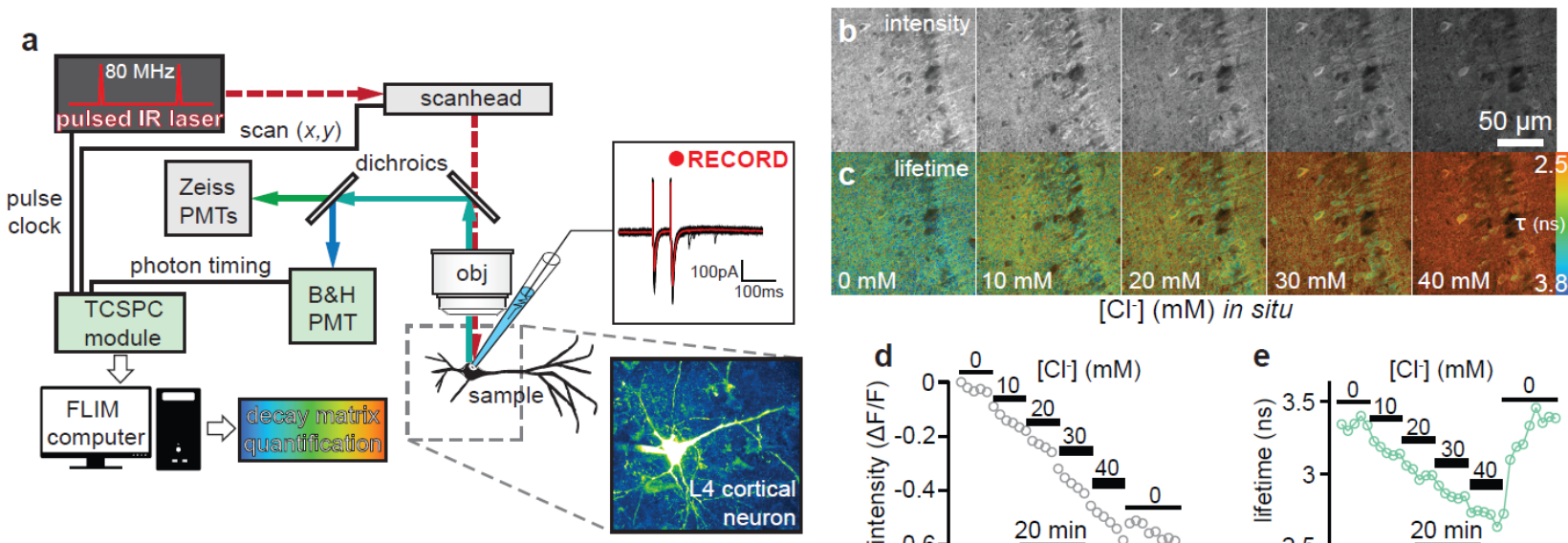

$\left[\mathrm{Cl}^{-}\right](\mathrm{mM})$ in situ

f

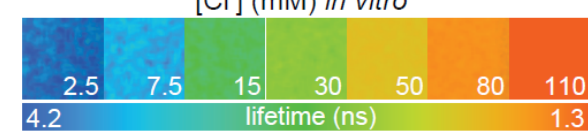

g

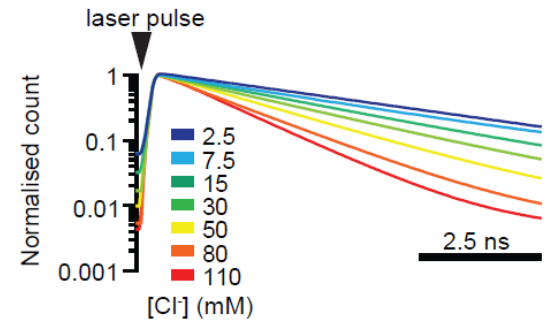

h

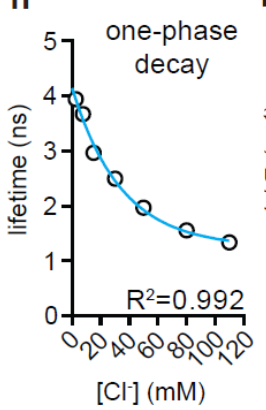

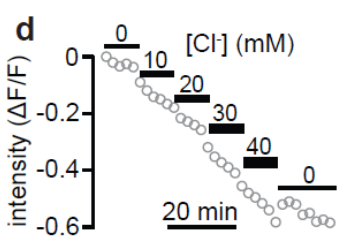

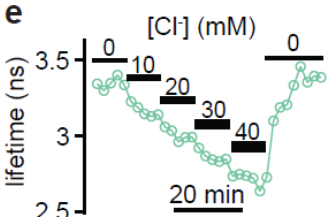

i

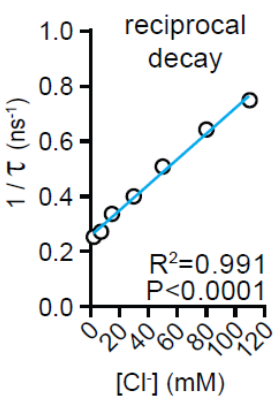

j

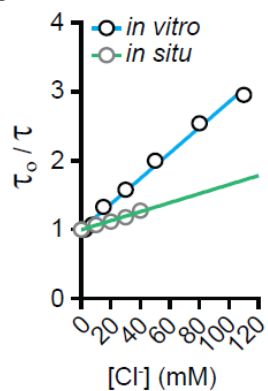

k

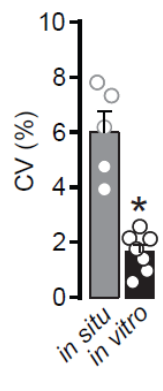

bulk-load (in situ calibration) I।

Neuron pipette-load (in vitro calibration)"
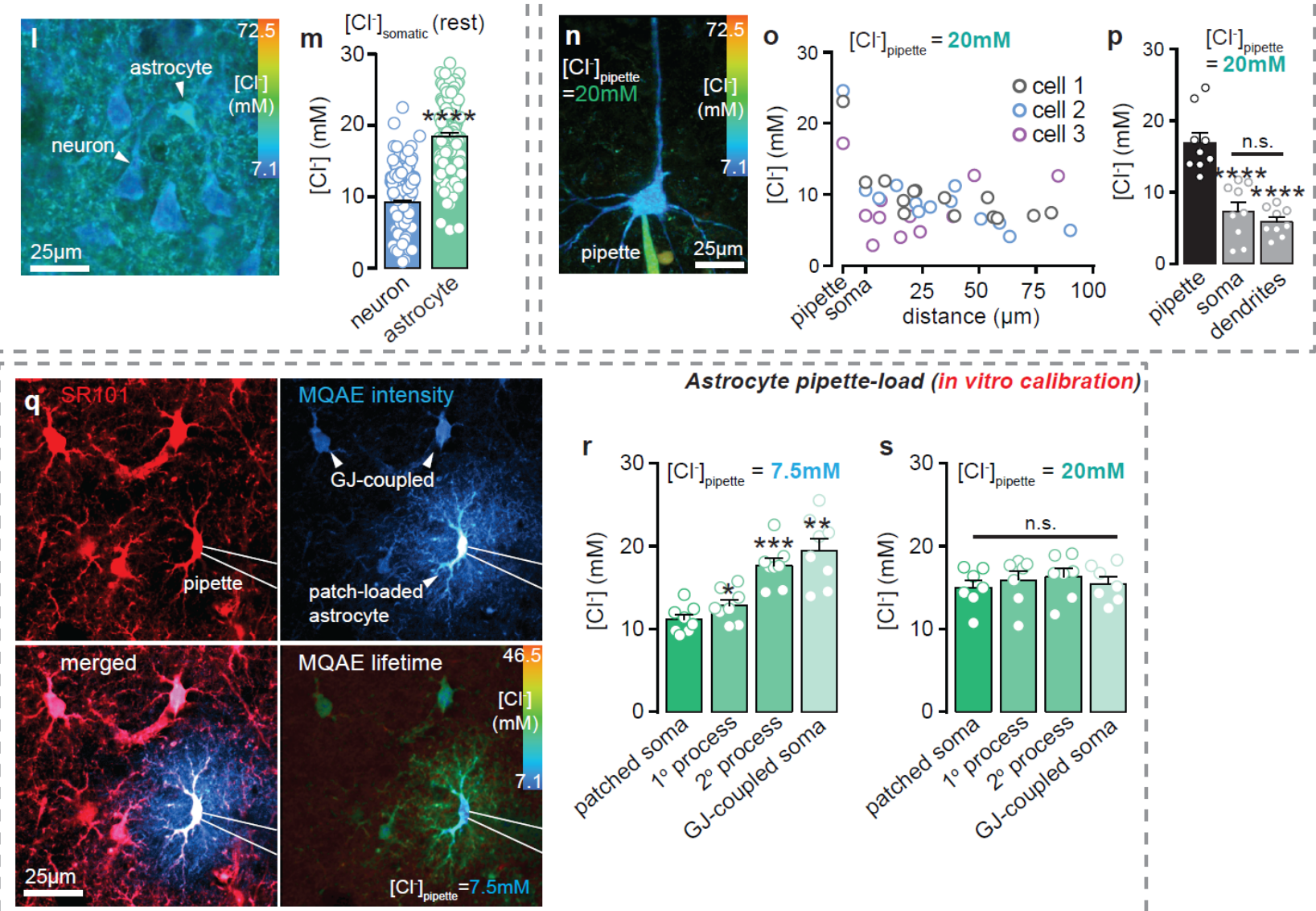

Astrocyte pipette-load (in vitro calibration)|

r

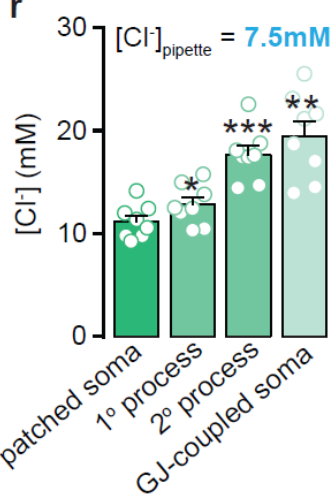

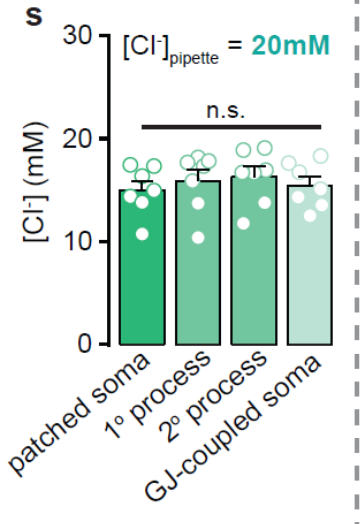




\section{Figure 1. Fluorescence Lifetime Imaging reveals distinct $\mathrm{Cl}^{-}$handling in neurons and} astrocytes. a) Schematic of the time-correlated single photon counting FLIM setup pairing 2P laser imaging system with a Becker \& Hickl SPC FLIM module and whole-cell patch clamp electrophysiology. b) MQAE-intensity image series of CA1 hippocampal neurons in the presence of nigericin and tributyltin to equilibrate $\left[\mathrm{Cl}^{-}\right]_{\mathrm{o}}:\left[\mathrm{Cl}^{-}\right]_{\mathrm{i}}$ across plasma membranes. $\left[\mathrm{Cl}^{-}\right]_{\mathrm{o}}$ was sequentially increased to alter $\left[\mathrm{Cl}^{-}\right]_{\mathrm{i}}$ and therefore MQAE-intensity. c) MQAE-FLIM readouts from images in ' $b$ '. d) Intensity measures from CA1 neuronal somata when $\left[\mathrm{Cl}^{-}\right]_{\mathrm{o}}$ is manipulated from 0 to $40 \mathrm{mM}$. Note that the signal does not reach steady state, nor does it recover to baseline upon washout. e) Corresponding MQAE- $\left[\mathrm{Cl}^{-}\right]_{\mathrm{i}}$ values for intensity measurements in ' $d$ '. Note that MQAE-FLIM signals reach steady state and that the $\mathrm{Cl}^{-}$washout is quantifiable. f) Example FLIM images of in vitro MQAE calibration. g) Normalized MQAE lifetime curves at varying $\left[\mathrm{Cl}^{-}\right]$. h) MQAE-FLIM calibration data fit to a one-phase exponential decay curve consistent with a collisional quenching model. i) The reciprocal of the curve in 'd' confirms a linear relationship. j) KSV plots comparing calibrations obtained in vitro (in bulkloaded cells) and in vitro (in sealed pipettes). k) Coefficient of variance (CV) plots comparing in vitro and in situ calibration data shows that the variability of lifetime readouts is lower in vitro $(\mathrm{P}<0.05$, student's t-test). I) Exemplar image of layer 4 cortical neurons and an astrocyte bulk loaded with MQAE. m) Mean somatic $\left[\mathrm{Cl}^{-}\right]_{\mathrm{i}}$ measurements with MQAE-FLIM reveal significantly higher basal $\left[\mathrm{Cl}^{-}\right]_{\mathrm{i}}$ in astrocytes $(\mathrm{n}=111$ cells) compared to neurons $(\mathrm{n}=197$ cells)(slices $=6, * * * * \mathrm{P}<0.0001$, student's t-test). n) Z-projection MQAE-FLIM image of layer 4 pyramidal neuron patch clamped with MQAE $(6 \mathrm{mM})$ and set $\left[\mathrm{Cl}^{-}\right]_{\mathrm{i}}(20 \mathrm{mM})$ in the pipette. o) Quantification of $\left[\mathrm{Cl}^{-}\right]_{\mathrm{i}}$ plotted vs distance from the soma for three example cells to measure the precipitous drop in $\left[\mathrm{Cl}^{-}\right]_{\mathrm{i}}$ from the pipette to distal dendrites. p) Comparison of average $\left[\mathrm{Cl}^{-}\right]_{\mathrm{i}}$ readouts of all cells patched with $\left[\mathrm{Cl}^{-}\right]_{\text {pipette }}=20 \mathrm{mM}(\mathrm{n}=9$ cells, $* * * * \mathrm{P}<0.0001$, one-way ANOVA with Tukey test). q) Astrocytes identified by SR101 staining (top left) were patch clamped and dialysed with MQAE (top right) $7.5 \mathrm{mM} \mathrm{Cl}^{-}$. MQAE signal was detected in gapjunctionally (GJ) coupled astrocytes. r) Average MQAE-FLIM measurements comparing somatic $\left[\mathrm{Cl}^{-}\right]_{\mathrm{i}}$ to $1^{\circ}$ and $2^{\circ}$ processes $(* \mathrm{P}=0.0171$ and $* * * \mathrm{P}=0.0002$, respectively), as well as to somatic ROIs from GJ-coupled astrocytes $(* * \mathrm{P}=0.0042)$ when $\left[\mathrm{Cl}^{-}\right]_{\text {pipette }}=7.5 \mathrm{mM}(\mathrm{n}=8$ slices, data compared to patched soma as a control, one-way ANOVA with Tukey test). s) Average MQAE-FLIM comparisons when $\left[\mathrm{Cl}^{-}\right]_{\text {pipette }}=20 \mathrm{mM}(\mathrm{n}=7$ slices, $\mathrm{P}>0.05$, one-way ANOVA with Tukey test). 
172
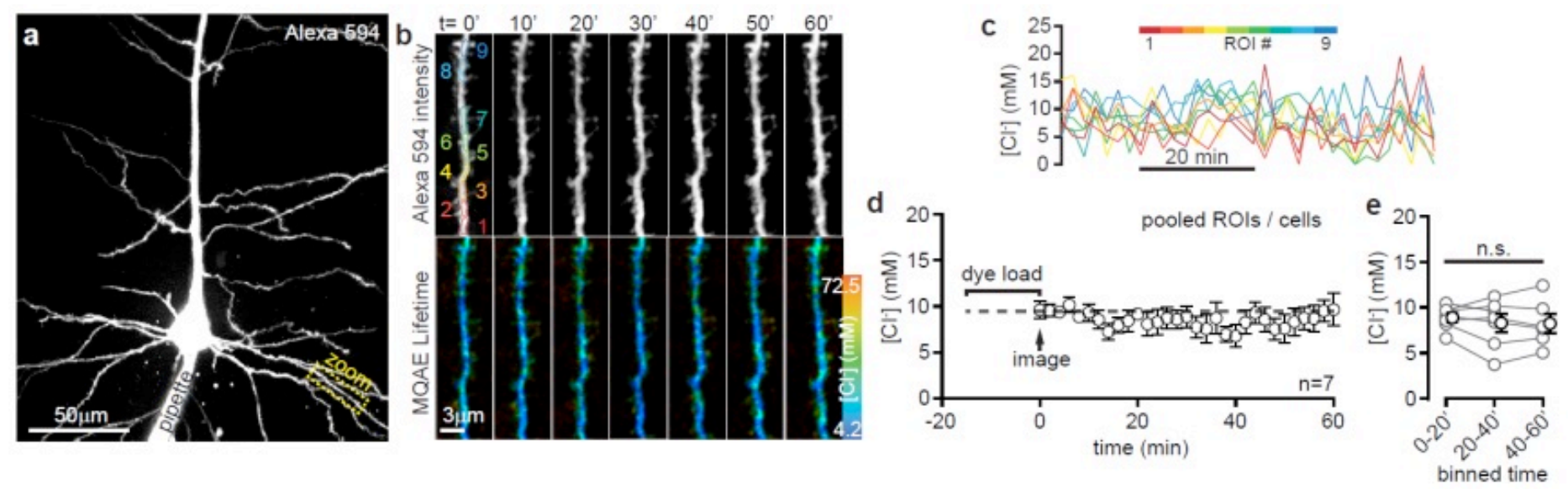

173

174 Supplemental Figure 1. $M Q A E-\left[\mathrm{Cl}^{-}\right]_{i}$ readouts are stable in dendrites. a) Maximum intensity

175 projection z-stack image of a cortical neuron patch-loaded with Alexa594 (presented emission)

176 and MQAE. Dashed yellow box denotes basal dendrite imaged in ' $b$ ' and 'c'. b) Sample Alexa

177594 intensity (top panels) and MQAE-FLIM (bottom panels) image series to monitor dendritic

178 morphology and maintain a stable focal plane for MQAE-FLIM. Intensity channel was used to

179 map ROIs for MQAE-FLIM analysis. c) Color-coded MQAE-[Cl' $]_{\mathrm{i}}$ traces from dendrite in ' $b$ '.

180 d) Average dendritic $\left[\mathrm{Cl}^{-}\right]_{\mathrm{i}}$ over time following a $15 \mathrm{~min}$ dye load period. Dendritic $\left[\mathrm{Cl}^{-}\right]_{\mathrm{i}} \mathrm{was}$

181 stable over the course of 60 min imaging sessions ( $\mathrm{n}=7$ cells). e) Quantification of dendritic $\left[\mathrm{Cl}^{-}\right.$

$182]_{\mathrm{i}}$ in $20 \mathrm{~min}$ intervals. No net change in $\left[\mathrm{Cl}^{-}\right]_{\mathrm{i}}$ was observed $(\mathrm{P}>0.05$, Tukey's test on one-way

183 ANOVA), suggesting the relative impact of changes to the cytosolic microenvironment on

184 MQAE-FLIM are negligible. 


\section{Bulk- and patch-loaded cells report expected $\left[\mathrm{Cl}^{-}\right]_{i}$ with MQAE-FLIM}

Resting $\left[\mathrm{Cl}^{-}\right]_{\mathrm{i}}$ is reported to range from $6 \mathrm{mM}$ to $13 \mathrm{mM}$ in mature neurons (Delpire and Staley, 2014; Kuner and Augustine, 2000; Staley and Proctor, 1999). We sought to confirm that MQAE-FLIM measures of neuronal $\left[\mathrm{Cl}^{-}\right]_{\mathrm{i}}$ matched basal values reported in these previous studies. In neurons bulk loaded with MQAE, mean resting $M Q A E-\left[\mathrm{Cl}^{-}\right]_{\mathrm{i}}$ was calculated to be values $($ Fig $11, \mathrm{~m}) .\left[\mathrm{Cl}^{-}\right]_{\mathrm{i}}$ was significantly higher in astrocytes $(18.48 \pm 0.5 \mathrm{mM})$ visually identified by cell morphology or by co-staining with SR101 (Fig 11,m), closely matching measurements in cell culture (Gensch et al., 2015).

Next, we dialyzed MQAE by whole-cell patch clamp to compare MQAE-FLIM measures using in vitro calibration data in the soma and dendrites. Layer $4 / 5$ cortical neurons were patch clamped with $\left[\mathrm{Cl}^{-}\right]_{\text {pipette }}=20 \mathrm{mM}$, a commonly used concentration with $\mathrm{Ag} / \mathrm{AgCl}$ electrodes, and $\left[\mathrm{Cl}^{-}\right]_{\mathrm{i}}$ was measured at several distance intervals distal to the soma (Fig 1n,o). By calculating $M Q A E-\left[\mathrm{Cl}^{-}\right]_{\mathrm{i}}$ with in vitro calibration values, we observed that somatic $\left[\mathrm{Cl}^{-}\right] \mathrm{i}$ was consistently

204 lower than the $20 \mathrm{mM}\left[\mathrm{Cl}^{-}\right]_{\text {pipette }}$ and that the lower $M Q A E-\left[\mathrm{Cl}^{-}\right]_{\mathrm{i}}$ readouts were stable throughout the proximal and distal dendrites (Fig 1n,o). Cellular $\left[\mathrm{Cl}^{-}\right]_{\mathrm{i}}$ in patched neurons closely matched measures from in situ bulk loading experiments (from Fig 11,m), suggesting both methods

207 accurately report resting $\left[\mathrm{Cl}^{-}\right]_{\mathrm{i}}$ levels (Fig 1p). As an important control, dendritic MQAE-FLIM 208 readouts were stable over $1 \mathrm{hr}$ (SFig 1), suggesting $M Q A E-\left[\mathrm{Cl}^{-}\right]_{\mathrm{i}}$ measures are minimally 
The precipitous drop from $\left[\mathrm{Cl}^{-}\right]_{\text {pipette }}$ to somatic $\left[\mathrm{Cl}^{-}\right]_{\mathrm{i}}$ could be due to: (1) homeostatic $\mathrm{Cl}^{-}$

211

212

213

214

215

216

217

218

219

220

221

222

223

224

225

226 227 Erausquin et al., 2005; Doyon et al., 2016).

efflux by $\mathrm{K}^{+}-\mathrm{Cl}^{-}$cotransport, or (2) unpredictable interactions between MQAE and the cytosolic microenvironment. The latter case assumes $\left[\mathrm{Cl}^{-}\right]_{\mathrm{i}}$ closely matches $\left[\mathrm{Cl}^{-}\right]_{\text {pipette }}(20 \mathrm{mM})$ and that the measured $M Q A E-\left[\mathrm{Cl}^{-}\right]_{\mathrm{i}}$ is artifactually altered by nonspecific anion quenching. We explored these possibilities by patch loading MQAE in astrocytes, which do not express KCC2 (Williams et al., 1999) and their $\left[\mathrm{Cl}^{-}\right]_{\mathrm{i}}$ is reported to range from 20-40 mM (Gensch et al., 2015; Untiet et al., 2017). Patched astrocytes were dialyzed with a $\left[\mathrm{Cl}^{-}\right]_{\text {pipette }}$ concentration much lower than our in situ measure for astrocyte $\left[\mathrm{Cl}^{-}\right]_{\mathrm{i}}$ but closer to neuronal $\left[\mathrm{Cl}^{-}\right]_{\mathrm{i}}(7.5 \mathrm{mM})$. If hypothesis (1) was correct then homeostatic $\mathrm{Cl}^{-}$import would increase $\left[\mathrm{Cl}^{-}\right]_{\mathrm{i}}$ to $\sim 18 \mathrm{mM}$ (Fig 11) due to high glial expression of NKCC1 (Su et al., 2002; Untiet et al., 2017). Somatic $M Q A E-\left[\mathrm{Cl}^{-}\right]_{\mathrm{i}}$ in patched astrocytes was higher $(11.16 \pm 0.6 \mathrm{mM})$ than $\left[\mathrm{Cl}^{-}\right]$pipette, consistent with the observation that astrocytes maintain a higher $\left[\mathrm{Cl}^{-}\right]_{\mathrm{i}}$ than neurons (Fig 1q,r)(Kettenmann and Schachner, 1985; MacVicar et al., 1989; Untiet et al., 2017). Distal measures revealed a progressive increase in $\left[\mathrm{Cl}^{-}\right]_{\mathrm{i}}$ in large primary- $\left(1^{\circ}\right)$ to smaller secondary $\left(2^{\circ}\right)$ processes of patched astrocytes, with peak measures from astrocyte somata coupled via gap-junctions (GJ)(19.46 \pm 1.46 mM, Fig 1r). In contrast, we observed a slight but reliable decrease in $\left[\mathrm{Cl}^{-}\right]_{\mathrm{i}}$ across all ROIs (Fig 1s) in astrocytes loaded with $\left[\mathrm{Cl}^{-}\right]_{\text {pipette }}=20 \mathrm{mM}$, consistent with an homeostatic decrease by $\mathrm{KCC} 3$ (Cordero- 
$2 \mathrm{ab}$ ), suggesting that MQAE diffusion was in stable equilibrium and that its lifetime is not appreciably impacted by hydrolysis (Koncz and Daugirdas, 1994). We again observed a marked decrease in somatic $M Q A E-\left[\mathrm{Cl}^{-}\right]_{\mathrm{i}}$ compared to $M Q A E-\left[\mathrm{Cl}^{-}\right]_{\text {pipette }}$ (Fig 3ac) with gradual, distancedependent reductions in dendrites suggesting substantial $\mathrm{Cl}^{-}$efflux throughout the dendritic tree. Bath application of furosemide $(200 \mu \mathrm{M})$ significantly increased dendritic $\left[\mathrm{Cl}^{-}\right]_{\mathrm{i}}$ at binned ROIs equidistant to the soma (Fig 2c-e), indicating that the low dendritic $\left[\mathrm{Cl}^{-}\right]_{\mathrm{i}}$ required $\mathrm{KCC} 2$. Applying furosemide together with picrotoxin to inhibit $\mathrm{GABA}_{\mathrm{A}}$-receptors similarly increased $\left[\mathrm{Cl}^{-}\right]_{\mathrm{i}}$ by blocking tonic $\mathrm{Cl}^{-}$efflux from $\mathrm{GABA}_{\mathrm{A}} \mathrm{R}$ when $E_{\mathrm{Cl}}$ is depolarized from holding potential $\left(V_{m}=-60 \mathrm{mV}\right)(\mathrm{Fig} 2 \mathrm{~d}, \mathrm{e})$. Interestingly, $\left[\mathrm{Cl}^{-}\right]_{\mathrm{i}}$ was significantly lower in $2^{\circ}$ versus $1^{\circ}$ dendrites (Fig 2f), consistent with the observation that $\mathrm{KCC} 2$ is evenly distributed in dendrites and therefore $\mathrm{Cl}^{-}$handling should be more efficient where the surface area to volume ratio is high (Doyon et al., 2011). These data suggest neurons defend their $\mathrm{Cl}^{-}$gradients by $\mathrm{KCC} 2-$ transport.

KCC2 transport activity is highly regulated by kinase-dependent phosphorylation via the With No-Lysine (K) (WNK) and Ste20p-related Proline Alanine-rich Kinases (SPAK) (Alessi et al., 2014). Phosphorylation or dephosphorylation of threonines (T) T906 and T1007 on the KCC2 c-terminus cause transporter hypo- or hyperfunction, respectively (Friedel et al., 2015; Kahle et al., 2013; Rinehart et al., 2009). To further explore KCC2's role in establishing $\mathrm{Cl}^{-}$ gradients, we repeated the above experiments in knock-in mice in which T906 and T1007 were mutated to alanine (A) (i.e., T906A and T1007A, henceforth " $\mathrm{KCC} 2{ }^{\mathrm{A} / \mathrm{A} \text { ") }}$ to mimic $\mathrm{KCC} 2$ dephosphorylation and constitutive activation (Friedel et al., 2015; Heubl et al., 2017; Moore et al., 2018; Pisella et al., 2019; Watanabe et al., 2019). We observed a sharp drop in somatodendritic $M Q A E-\left[\mathrm{Cl}^{-}\right]_{\mathrm{i}}$ in patched $\mathrm{KCC} 2^{\mathrm{A} / \mathrm{A}}$ neurons compared to wild-type controls $\left(\mathrm{KCC} 2^{\mathrm{WT}}\right)$, 
consistent with an increased pump capacity of $\mathrm{KCC}^{\mathrm{A}} \mathrm{A}$ (Fig $2 \mathrm{~g}$ ). Additionally, we found no difference in equidistant $\left[\mathrm{Cl}^{-}\right]_{\mathrm{i}}$ measures between pyramidal neurons in brain slices from control rat versus mouse $\left(\mathrm{KCC} 2{ }^{\mathrm{WT}}\right)$ (control and $\mathrm{KCC} 2{ }^{\mathrm{WT}}$ groups from Fig $2 \mathrm{e}, \mathrm{g}$, respectively, $\mathrm{P}>0.05$ by two-way ANOVA). This similarity suggests that the $\mathrm{KCC} 2$ extrusion capacity is consistent between these species. We conclude that MQAE-FLIM can detect dynamic fluctuations in $\left[\mathrm{Cl}^{-}\right]_{\mathrm{i}}$ through manipulation of $\mathrm{KCC} 2$ activity, and that discrepancy between $M Q A E-\left[\mathrm{Cl}^{-}\right]_{\mathrm{i}}$ and $M Q A E-$ $\left[\mathrm{Cl}^{-}\right]_{\text {pipette }}$ is primarily due to homeostatic $\mathrm{Cl}^{-}$extrusion.

If the $M Q A E-\left[\mathrm{Cl}^{-}\right]_{\text {pipette }}: M Q A E-\left[\mathrm{Cl}^{-}\right]_{\mathrm{i}}$ mismatch was due to the cytosolic environment, somatic $\left[\mathrm{Cl}^{-}\right]_{\mathrm{i}}$ readouts from Fig 2 would be closer to $80 \mathrm{mM}$ instead of the recorded $\sim 30-40$ $\mathrm{mM}$, and true $\left[\mathrm{Cl}^{-}\right]_{\mathrm{i}}$ would be close to a ceiling and likely not amenable to increase. We tested whether $M Q A E-\left[\mathrm{Cl}^{-}\right]_{\mathrm{i}}$ in these conditions could be increased to match $\left[\mathrm{Cl}^{-}\right]_{\text {pipette }}$ by experimentally inhibiting $\mathrm{Cl}^{-}$fluxes. Neurons were voltage clamped at the calculated $E_{\mathrm{Cl}}$ for $\left[\mathrm{Cl}^{-}\right.$ ]$_{\text {pipette }}=80 \mathrm{mM}\left(E_{C l-}=-14 \mathrm{mV}\right)$, and a cocktail of blockers was applied to inhibit $\mathrm{Cl}^{-}$fluxes, including: picrotoxin $\left(\mathrm{GABA}_{A} \mathrm{R}\right)$, furosemide, bumetanide (NKCC1), niflumic acid (NFA, $\mathrm{Ca}^{2+}{ }_{-}$ activated $\mathrm{Cl}^{-}$channels), and 5-Nitro-2-(3-phenylpropylamino)benzoic acid (NPPB, VRACs). Under these conditions, somatic $\left[\mathrm{Cl}^{-}\right]_{\mathrm{i}}$ steadily increased from $36.83 \pm 2.1 \mathrm{mM}$ at break-in to a plateau of $64.11 \pm 1.8 \mathrm{mM}$ over $20 \mathrm{~min}$ (Fig 3a-c). This was accompanied by a volume increase (as evidenced by the increase in mean cross sectional area $=34.8 \%$, Fig $3 \mathrm{a}, \mathrm{b}, \mathrm{d}$ ) because $\mathrm{Cl}^{-}$ loading is a key driver of swelling (Rothman, 1985; Rungta et al., 2015). Together, these data refute hypothesis (2) and suggest that $M Q A E-\left[\mathrm{Cl}^{-}\right]_{\mathrm{i}}$ readouts can be used to quantify $\mathrm{Cl}^{-}$dynamics via transporter export and efflux through $\mathrm{Cl}^{-}$channels. 

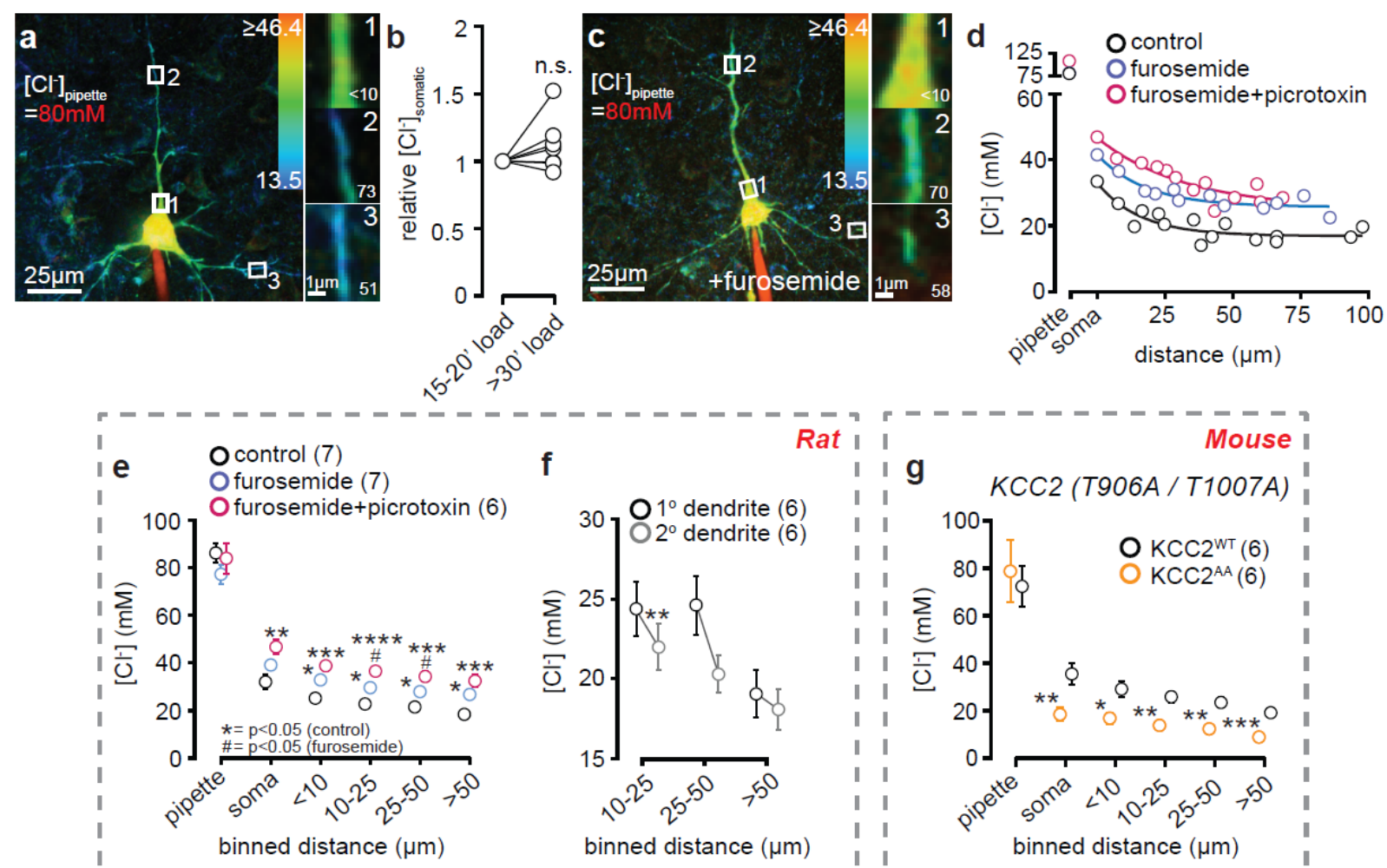

Rat i i
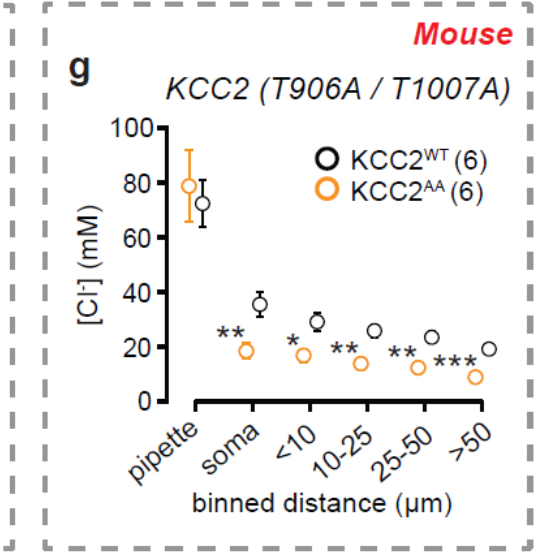

Figure 2. KCC2-dependent $\mathrm{Cl}^{-}$extrusion during high $\left[\mathrm{Cl}^{-}\right]_{i}$ challenge. a) Left panel: example maximum intensity projection (collapsed Z-stack) image of layer 4 neuron patch filled with $\left[\mathrm{Cl}^{-}\right.$ ]$_{\text {pipette }}=80 \mathrm{mM}$, normal ASF $\left[\mathrm{Cl}^{-}\right]_{\mathrm{o}}=136 \mathrm{mM}$, voltage clamped at $-60 \mathrm{mV}$. Right panels: zoomed ROIs from primary (panels 1\&2) and secondary (panel 3) dendrites at different distances from the soma (in $\mu \mathrm{m}$, bottom right values in figure panels). b) Quantification of average $\left[\mathrm{Cl}^{-}\right]_{\mathrm{i}}$ measures over time (each point represents whole-cell averages). $\left[\mathrm{Cl}^{-}\right]_{\mathrm{i}}$ stabilized after $15 \mathrm{~min}$ post whole-cell break-in, and MQAE-FLIM readouts did not change 30 min post break-in. c) Exemplar cell loaded with $\left[\mathrm{Cl}^{-}\right]_{\text {pipette }}=80 \mathrm{mM}$ in the presence of $\mathrm{KCC} 2$ blocker furosemide $(200$ $\mu \mathrm{M})$, normal ASF $\left[\mathrm{Cl}^{-}\right]_{\mathrm{o}}=136 \mathrm{mM}$, voltage clamped at $-60 \mathrm{mV}$. Zoom panels show higher steady-state $\left[\mathrm{Cl}^{-}\right]_{\mathrm{i}}$ measured by MQAE-FLIM compared to 'a', suggesting a $\mathrm{KCC} 2$-dependent $\mathrm{Cl}^{-}$efflux pathway. d) Plots of $\left[\mathrm{Cl}^{-}\right]_{\mathrm{i}}$ at varying distances from the soma. Application of furosemide alone, or furosemide+picrotoxin $(100 \mu \mathrm{M})$ increased steady state $\left[\mathrm{Cl}^{-}\right]_{\mathrm{i}}$ measures by MQAE-FLIM compared to control. e) Quantitative summary comparing drug treatments on $\left[\mathrm{Cl}^{-}\right.$ ]$_{\mathrm{i}}$ at respective distances $\left({ }^{*} \mathrm{P}<0.05\right.$ compared to control, ${ }^{\#} \mathrm{P}<0.05$ compared to furosemide). $\mathbf{f}$ )

292 Comparison of $\left[\mathrm{Cl}^{-}\right]_{\mathrm{i}}$ between primary and secondary dendrites at binned ROIs equidistant from the soma. $\left[\mathrm{Cl}^{-}\right]_{\mathrm{i}}$ measures were relatively lower in $2^{\circ} \mathrm{vs} 1^{\circ}$ dendrites at distances of $10-25 \mu \mathrm{m}$ $(* * \mathrm{P}=0.0062)$ from the soma, but not at distances $25-50 \mu \mathrm{m}(\mathrm{P}=0.0517)$ and $>50 \mu \mathrm{m}(\mathrm{P}=$ $0.2467)$, two-tailed paired t-tests. g) Quantitative analysis of $\left[\mathrm{Cl}^{-}\right]_{\mathrm{i}}$ by MQAE-FLIM in $\mathrm{KCC}^{\mathrm{A} / \mathrm{A}}$ mice compared to WT controls patch loaded with $\left[\mathrm{Cl}^{-}\right]_{\text {pipette }}=80 \mathrm{mM}$, normal ASF $\left[\mathrm{Cl}^{-}\right]_{\mathrm{o}}=136$ $\mathrm{mM}$, voltage clamped at $-60 \mathrm{mV} .\left[\mathrm{Cl}^{-}\right]_{\mathrm{i}}$ was significantly lower in $\mathrm{KCC} 2^{\mathrm{A} / \mathrm{A}}$ neurons compared to $\mathrm{KCC} 2{ }^{\mathrm{WT}}$ (from left to right, $\mathrm{P}=0.0082,0.0161,0.0014,0.0012,0.0006$ ), consistent with an increased extrusion capacity of $\mathrm{KCC} 2$. 

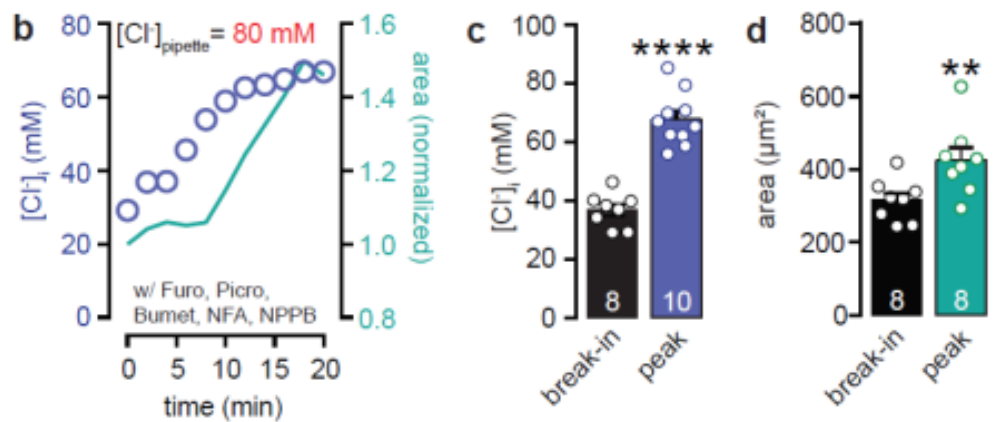

305

306

307

308

309

310

311

312

313

314

315

316

317

Figure 3. Inhibiting putative routes of $\mathrm{Cl}^{-}$efflux leads to dramatic increase in $\left[\mathrm{Cl}^{-}\right]_{\text {i. a) }}$ Example MQAE-FLIM images at whole-cell break in (left panel) and $20 \mathrm{~min}$ after (right panel) of cell patch clamped with $\left[\mathrm{Cl}^{-}\right]_{\text {pipette }}=80 \mathrm{mM}$, normal ASF $\left[\mathrm{Cl}^{-}\right]_{\mathrm{o}}=136 \mathrm{mM}$, voltage clamped at $-14 \mathrm{mV}$. Experiment performed with furosemide $(200 \mu \mathrm{M})$, picrotoxin $(100 \mu \mathrm{M})$ bumetanide $(50 \mu \mathrm{M})$, NFA $(100 \mu \mathrm{M})$, and NPPB $(100 \mu \mathrm{M})$ in the ACSF. b) Quantification of somatic $\left[\mathrm{Cl}^{-}\right]_{\mathrm{i}}$ and cross-sectional area over time in ' $a$ '. c) Summary of peak $\left[\mathrm{Cl}^{-}\right]_{\mathrm{i}}$ measures by MQAE compared to whole-cell break-in $(0-1 \mathrm{~min})(* * * * \mathrm{P}<0.0001$, two-tailed paired t-test $)$. d) Comparison of somatic swelling as measured by cross-sectional area ( $* * \mathrm{P}=0.0018$, two-tailed paired t-test).

\section{Local GABA uncaging corroborates MQAE lifetime}

As final confirmation that MQAE-FLIM is accurate, we compared spatially coupled FLIM readouts to $\mathrm{E}_{\mathrm{GABA}}$ measured by local two-photon of uncaging Rubi-GABA (Rial Verde et al., 2008). Rubi-GABA (0.5 mM) was locally applied and photolyzed adjacent to the somatic MQAE-FLIM ROI. In this way we would achieve reasonable voltage clamp in the soma with minimal space clamp artifacts (Fig 4a) (Williams and Mitchell, 2008). These experiments were performed in the absence of the intracellular $\mathrm{K}^{+}$-channel blocker $\mathrm{Cs}^{+}$to prevent perturbation of KCC2 function (Blaesse et al., 2009; Williams and Payne, 2004). In neurons patched with $\left[\mathrm{Cl}^{-}\right.$ ]$_{\text {pipette }}=80 \mathrm{mM}$, Rubi-GABA was uncaged at $-80 \mathrm{mV}$ to $+20 \mathrm{mV}$ and $\left[\mathrm{Cl}^{-}\right]_{\mathrm{i}}$ was calculated from 

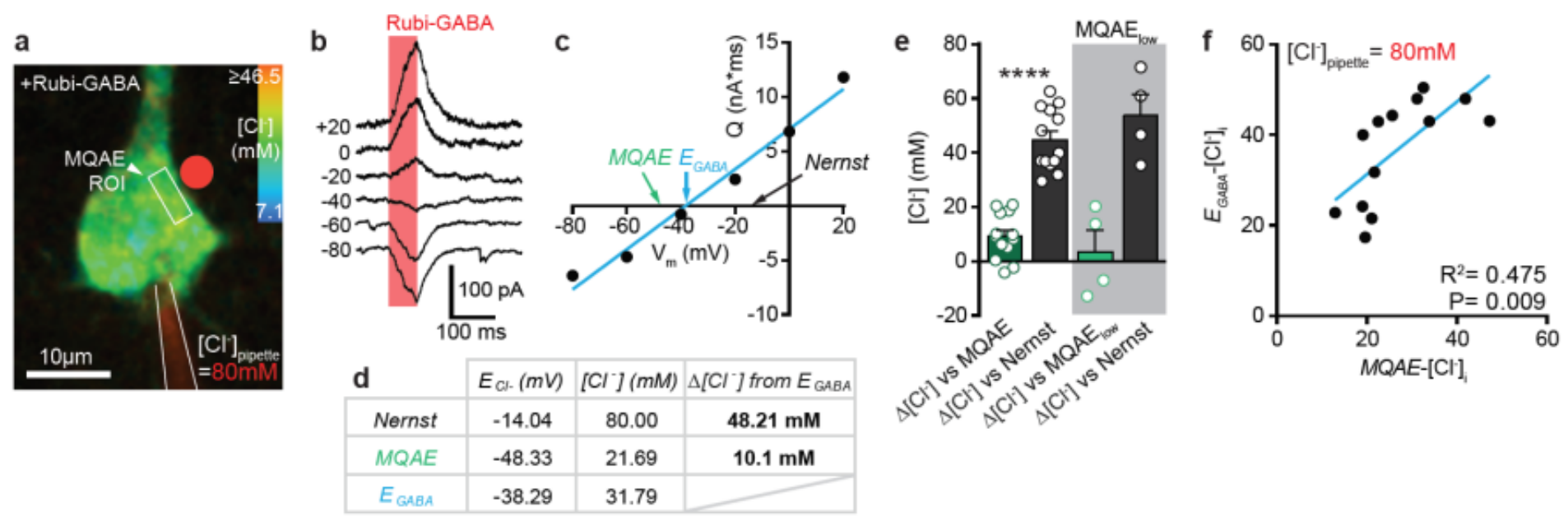

Figure 4. Comparison of MQAE- $\left[\mathrm{Cl}^{-}\right]_{\mathbf{i}}$ to $\mathbf{E}_{\mathbf{G A B A}}-\left[\mathrm{Cl}^{-}\right]_{\text {i. }}$ a) Example image of layer 4 neuron patch-loaded with $\left[\mathrm{Cl}^{-}\right]_{\text {pipette }}=80 \mathrm{mM}$, normal ASF $\left[\mathrm{Cl}^{-}\right]_{\mathrm{o}}=136 \mathrm{mM}$. Rubi-GABA was locally applied $(0.5 \mathrm{mM})$ by puff electrode and photolyzed adjacent to the soma (red dot) by $2 \mathrm{P}-$ different holding potentials. c) Charge $(\mathrm{Q})$ and membrane voltage $\left(\mathrm{V}_{\mathrm{m}}\right)$ plot of Rubi-GABA

340 responses. EGABA is graphically compared to $\mathrm{Cl}^{-}$reversal calculated by MQAE measurement, 341 as well the $\mathrm{E}_{\mathrm{Cl}}$ - estimation that assumes $\left[\mathrm{Cl}^{-}\right]_{\mathrm{i}}=\left[\mathrm{Cl}^{-}\right]_{\text {pipette }}(80 \mathrm{mM})$. d) Tabular results from

342 exemplar experiment 'a-c' showing the calculated values for $\mathrm{E}_{\mathrm{Cl}}$ - based on the pipette solution 343 (Nernst), the MQAE-FLIM measurement, and the $\mathrm{E}_{\mathrm{GABA}}$ measurement; the respective predicted $344\left[\mathrm{Cl}^{-}\right]_{\mathrm{i}}$ values; and the differences in the predicted $\left[\mathrm{Cl}^{-}\right]_{\mathrm{i}}$. e) Comparison of $\left[\mathrm{Cl}^{-}\right]_{\mathrm{i}}$ predicted by $345 \mathrm{E}_{\mathrm{GABA}}$ to $M Q A E-\left[\mathrm{Cl}^{-}\right]_{\mathrm{i}}$ and Nernst, $* * * * \mathrm{P}<0.0001$. f) Correlation plot between calculated $E_{G A B A^{-}}$ $346 \quad\left[\mathrm{Cl}^{-}\right]_{\mathrm{i}}$ and $M Q A E-\left[\mathrm{Cl}^{-}\right]_{\mathrm{i}}$ values. 


\section{Mapping KCC2/NKCC1-dependent control of dendritic $\mathrm{Cl}^{-}$gradients}

351 Proximal basal dendrites $\left(\left[\mathrm{Cl}^{-}\right]_{\text {pipette }}=7.5 \mathrm{mM}\right)$ were imaged by MQAE-FLIM before and after

352 bath application of furosemide or the NKCC1 inhibitor bumetanide (Fig 5a-d). Quantitative and 353 reversible increases in $M Q A E-\left[\mathrm{Cl}^{-}\right]_{\mathrm{i}}$ were observed in furosemide, consistent with disruption of

354 basal $\mathrm{Cl}^{-}$efflux by KCC2 (Fig 5a-c). On the other hand, bath application of bumetanide $(50 \mu \mathrm{M})$

355 to selectively block NKCC1 decreased resting $\left[\mathrm{Cl}^{-}\right]_{\mathrm{i}}$ due to reduced $\mathrm{Cl}^{-}$import. As a positive

356 control, membrane depolarization to $+30 \mathrm{mV}$ also increased $\left[\mathrm{Cl}^{-}\right]_{\mathrm{i}}$ in the presence of furosemide

357 or bumetanide (Fig 5c,d) but also in the absence of either blocker (Fig 5e), consistent with an

358 increased driving force for $\mathrm{Cl}^{-}$entry through tonic $\mathrm{GABA}_{\mathrm{A}} \mathrm{R}$ activity and voltage-activated $\mathrm{Cl}^{-}$

359 channels. Thus, MQAE-FLIM has the sensitivity to measure millimolar contributions of $\mathrm{Cl}^{-}$

360 channels and transporters, as well as dynamic $\left[\mathrm{Cl}^{-}\right]_{\mathrm{i}}$ changes.

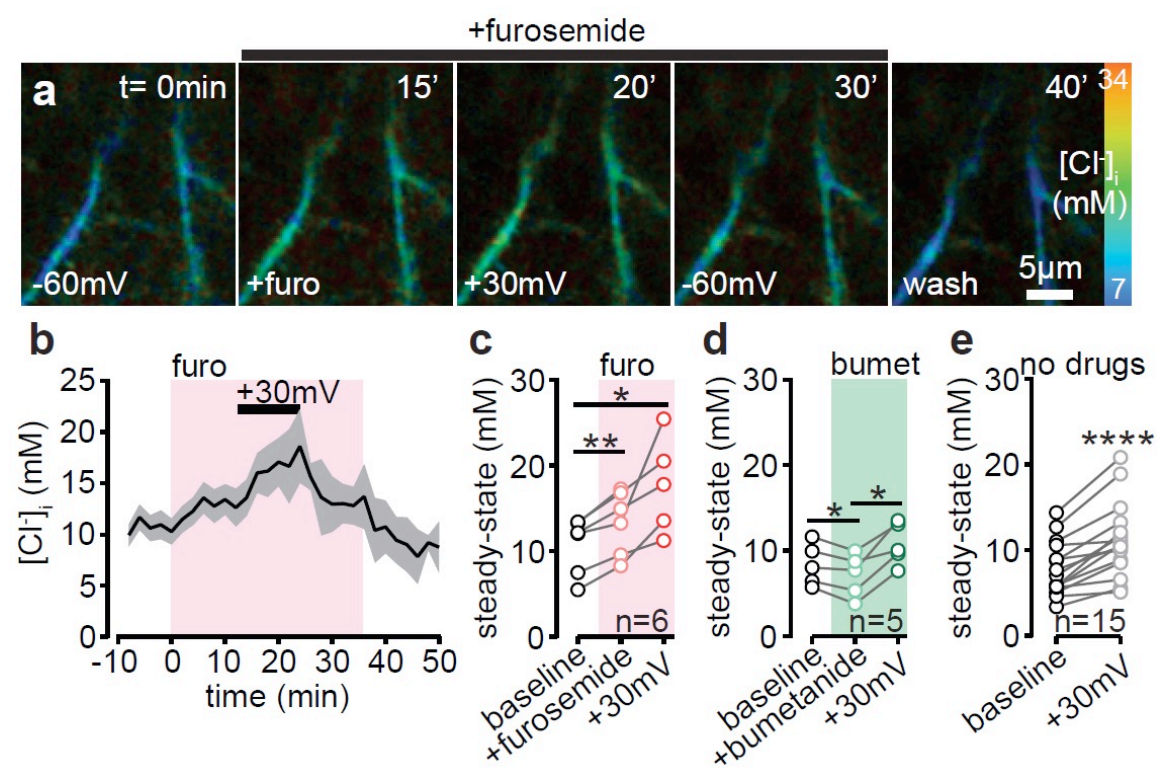


Figure 5. MQAE-FLIM can detect KCC2-dependent changes in $\left[\mathrm{Cl}^{-}\right]_{i}$ with millimolar precision. a) Example MQAE-FLIM image series of $\left[\mathrm{Cl}^{-}\right]_{\mathrm{i}}$ in a basal dendrite from a patch clamped layer 4 cortical neuron $\left(\left[\mathrm{Cl}^{-}\right]_{\text {pipette }}=7.5 \mathrm{mM}\right)$ in the presence of furosemide (furo, 200 $\mu \mathrm{M})$ and membrane depolarization $(+30 \mathrm{mV})$. b) Average trace of $\left[\mathrm{Cl}^{-}\right]_{\mathrm{i}}$ changes over time in response to furosemide application (pink box) and membrane depolarization $(n=6)$. c) Quantitative analysis comparing paired $\left[\mathrm{Cl}^{-}\right]_{\mathrm{i}}$ measurements before and after furosemide $(* * \mathrm{P}=$ $0.006)$ and membrane depolarization to $+30 \mathrm{mV}(* \mathrm{P}=0.0378)$, one-way ANOVA with Tukey test. d) Quantitative comparison of paired $\left[\mathrm{Cl}^{-}\right]_{\mathrm{i}}$ measurements before and after bumetanide (bumet, $50 \mu \mathrm{M}, * \mathrm{P}=0.026$ ) and membrane depolarization to $+30 \mathrm{mV}(* \mathrm{P}=0.0165)$, one-way ANOVA with Tukey test. e) Membrane depolarization alone is sufficient to increase dendritic $\left[\mathrm{Cl}^{-}\right]_{\mathrm{i}}, * * * * \mathrm{P}<0.0001$, two tailed paired t-test.

MQAE-FLIM reveals heterogeneous $\mathrm{Cl}^{-}$microdomains in cytotoxic edema

Rungta et al., 2015) although little is known about the spatiotemporal dynamics and regulation of blebbing (Murphy et al., 2008; Thompson et al., 2008; Weilinger et al., 2016; Weilinger et al., stimulation in dendrites to recapitulate this form of ischemic injury. We used a strategy that we previously developed to restrict the actions of bath applied NMDA to only single patched clamped neuron (Dissing-Olesen et al., 2014). In these experiments $6 \mathrm{mM} \mathrm{Mg}^{2+}$ was included in the aCSF perfusate to block tissue-wide NMDAR responses from bath applied NMDA. Only single L4/5 cortical neurons that were patch clamped and depolarized to $+30 \mathrm{mV}$ to relieve the NMDAR $\mathrm{Mg}^{2+}$ block responded to NMDA application $(20 \mu \mathrm{M})$ (Dissing-Olesen et al., 2014). In this way, swelling was restricted to the patched neuron throughout the experimental time course, 

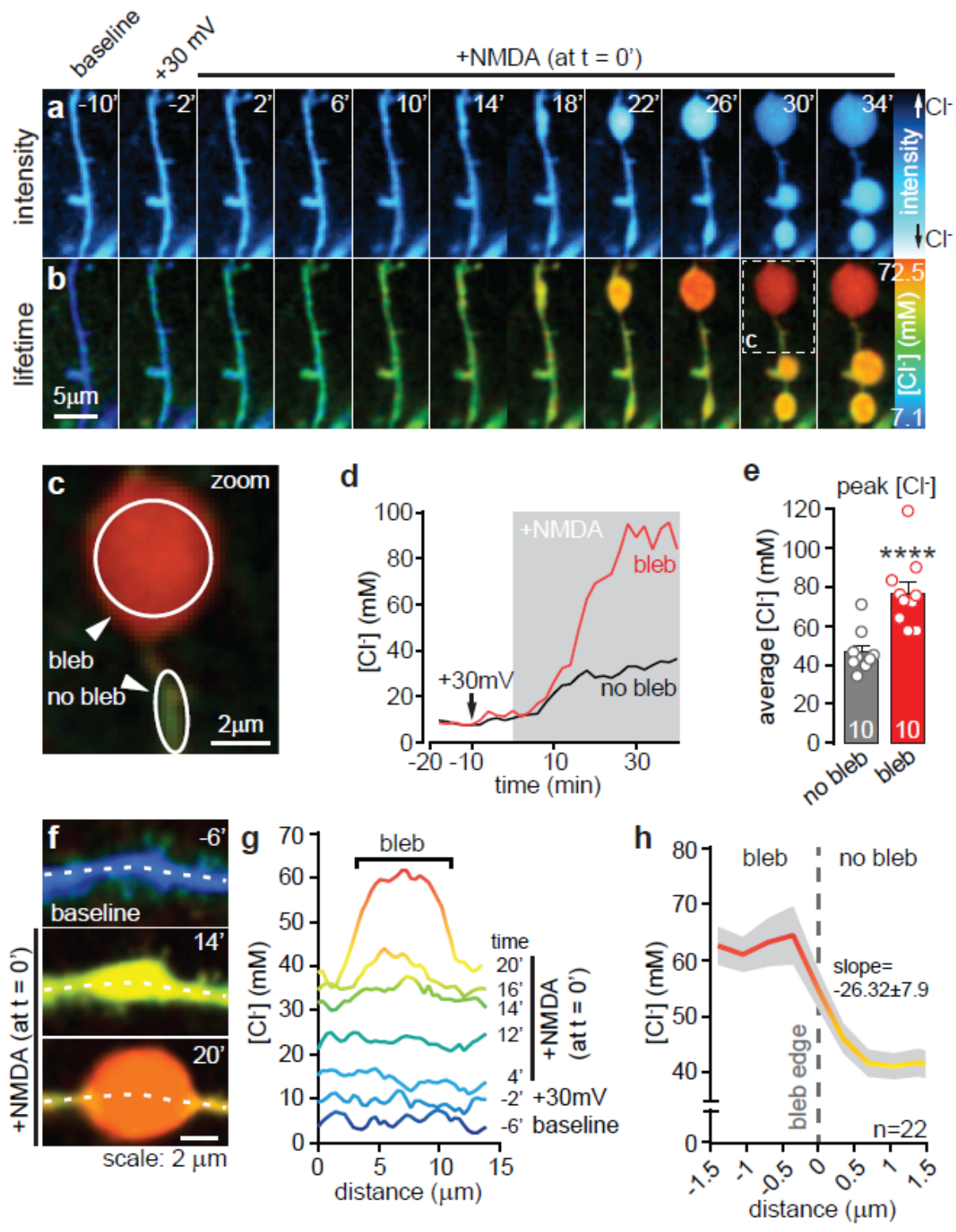

\section{Figure 6. MQAE-FLIM reveals heterogeneous $\left[\mathrm{Cl}^{-}\right]_{i}$ landscapes in excitotoxicity. a)} ]$_{\text {pipette }}=7.5 \mathrm{mM}$ ) before and after membrane depolarization and bath application of NMDA (20 $\mu \mathrm{M})$. b) MQAE-FLIM image data (same dendrite from ' $\mathrm{a}$ ') reveals dramatic $\left[\mathrm{Cl}^{-}\right]_{\mathrm{i}}$ heterogeneities during dendritic blebbing that are not resolved from intensity images. c) Zoomed image of dendrite from ' $b$ ' (white box $t=30 \mathrm{~min}$ ) depicting example ROIs encompassing blebbed 


7

and adjacent un-blebbed dendrite. d) Representative $\left[\mathrm{Cl}^{-}\right]_{\mathrm{i}}$ measurements over time from bleb and no bleb ROIs in the presence of NMDA. e) Quantitative summary of peak $\left[\mathrm{Cl}^{-}\right]_{\mathrm{i}}$ measures comparing MQAE-FLIM signal from blebbed and unblebbed ROIs, ****P $<0.0001$. f) MQAEFLIM time course showing the formation of a bleb. Time (in min) in the top right corner of the images indicates the time relative to application of NMDA (at $t=0 \mathrm{~min}$ ). Dotted white line indicates the ROI used to measure the pixel-to-pixel $\left[\mathrm{Cl}^{-}\right]_{i}$ levels over distance reported in ' $\mathrm{g}$ '. g) Spatial $\left[\mathrm{Cl}^{-}\right]_{\mathrm{i}}$ readouts from before, during, and after formation of the bleb shown in ' $\mathrm{f}$ '. Each line represents a $\left[\mathrm{Cl}^{-}\right]_{\mathrm{i}}$ measurement along a dendrite in a given frame. Corresponding time points are shown to the right of each trace. NMDA is applied at $t=0 \mathrm{~min}$. h) Average \pm s.e.m. of MQAE-FLIM $\left[\mathrm{Cl}^{-}\right]_{\mathrm{i}}$ readouts across bleb edges reveal a sharp decrease $\left[\mathrm{Cl}^{-}\right]_{\mathrm{i}}$ in from bleb to no bleb that occurs over less than a $1 \mu \mathrm{m}$ span. ' $\mathrm{n}$ ' denotes 22 blebs from 9 cells.

(1)

9

NMDA induced a rapid increase in $M Q A E-\left[\mathrm{Cl}^{-}\right]_{\mathrm{i}}$ followed by characteristic dendritic blebbing (Fig 6a,b) in depolarized neurons. We observed a surprising, heterogeneous distribution of $\left[\mathrm{Cl}^{-}\right]_{\mathrm{i}}$ in excitotoxic conditions, with higher $\left[\mathrm{Cl}^{-}\right]_{\mathrm{i}}$ constrained to dendrites that formed blebs

\begin{abstract}
(Fig 6c-e). Indeed, $\left[\mathrm{Cl}^{-}\right]_{\mathrm{i}}$ in blebs was significantly higher than adjacent dendrites that did not
\end{abstract}
bleb, often reaching peak concentrations of $\sim 80 \mathrm{mM}$ (Fig 6d,e). Pixel-to-pixel lifetime measurements showed that $\mathrm{Cl}^{-}$microdomains were spatially restricted across the length of dendrites (Fig 6f,g). We resolved precipitous drops in $\left[\mathrm{Cl}^{-}\right]_{\mathrm{i}}$ spanning a measured bleb edge length of $<1 \mu \mathrm{m}\left(\right.$ mean $\left[\mathrm{Cl}^{-}\right]_{\mathrm{i}}$ decrease $\left.=-26.32 \pm 7.9 \mathrm{mM} / \mu \mathrm{m}\right)($ Fig $6 \mathrm{~h})$, suggesting that the mobility of $\mathrm{Cl}^{-}$ions is constrained during blebbing.

\title{
Excitotoxic $\mathrm{Cl}^{-}$dysregulation in dendrites is $\mathrm{KCC} 2$-dependent
}

The mechanistic underpinnings of $\mathrm{Cl}^{-}$entry in dendritic blebbing is a point of contention.

Previous work has identified roles for VRACs in cultured neurons in vitro, and KCCs and 
$422 \mathrm{GABA}_{\mathrm{A}}$ receptors in acute brain slices (Allen et al., 2004; Inoue and Okada, 2007; Pond et al., 423 2006; Steffensen et al., 2015). We sought to dissect which $\mathrm{Cl}^{-}$transporter or channel activity 424 engendered the abnormally high but discrete $\left[\mathrm{Cl}^{-}\right]_{\mathrm{i}}$ accumulations in dendritic blebs. We first 425 confirmed the critical role for $\mathrm{Cl}^{-}$entry in swelling by reducing extracellular $\mathrm{Cl}^{-}$from $136.5 \mathrm{mM}$ to $18.5 \mathrm{mM}\left(\right.$ low $\left.\left[\mathrm{Cl}^{-}\right]_{\mathrm{o}}\right)$. Low $\left[\mathrm{Cl}^{-}\right]_{\mathrm{o}}$ blocked the $\mathrm{Cl}^{-}$influx as well as blebbing (Fig 7a-d) down to

427 control levels ( $+30 \mathrm{mV}$ only group, Fig 7d). Swelling also requires $\mathrm{Na}^{+}$-influx to drive $\mathrm{Cl}^{-}$entry

428

429

430 and satisfy Gibbs-Donnan equilibrium (Glykys et al., 2017). Consistent with this, reducing $\mathrm{Na}^{+}$ in otherwise normal ACSF decreased NMDA-induced $\mathrm{Cl}^{-}$influx (Fig 7a-d) and blebbing, confirming that concurrent $\mathrm{Na}^{+}$and $\mathrm{Cl}^{-}$loading is required.

We tested the role for $\mathrm{NKCC} 1$ in mediating $\mathrm{Cl}^{-}$entry in swelling by pre-incubating bumetanide prior to NMDA application. Interestingly, bumetanide increased the rate of $\mathrm{Cl}^{-}$ loading during the initial NMDA application but the peak $\left[\mathrm{Cl}^{-}\right]_{\mathrm{i}}$ accumulations during the plateau were not different from NMDA alone (Fig 7b,c). In contrast, blocking $\mathrm{KCC} 2$ with furosemide dramatically reduced the $\mathrm{Cl}^{-}$loading rate and average $\left[\mathrm{Cl}^{-}\right]_{\mathrm{i}}$ load (Fig 7a-d). $\mathrm{Cl}^{-}$channel inhibitors, such as 5-Nitro-2-(3-phenylpropylamino)benzoic acid (NPPB, $100 \mu \mathrm{M})$ to block VRACs, picrotoxin $(100 \mu \mathrm{M})$ for $\mathrm{GABA}_{\mathrm{A}}$ receptors, and niflumic acid (NFA, $\left.100 \mu \mathrm{M}\right)$ to block $\mathrm{Ca}^{2+}$ activated $\mathrm{Cl}^{-}$channels had no effect on NMDA-induced $\mathrm{Cl}^{-}$loading. Together, these data highlight the importance of the local regulation of $\mathrm{Cl}$ - microdomains to maintain dendrite volume. Further, our findings suggest that $\mathrm{Cl}^{-}$dysregulation in excitotoxic blebbing occurs principally through reversed uptake by $\mathrm{KCC} 2$. 

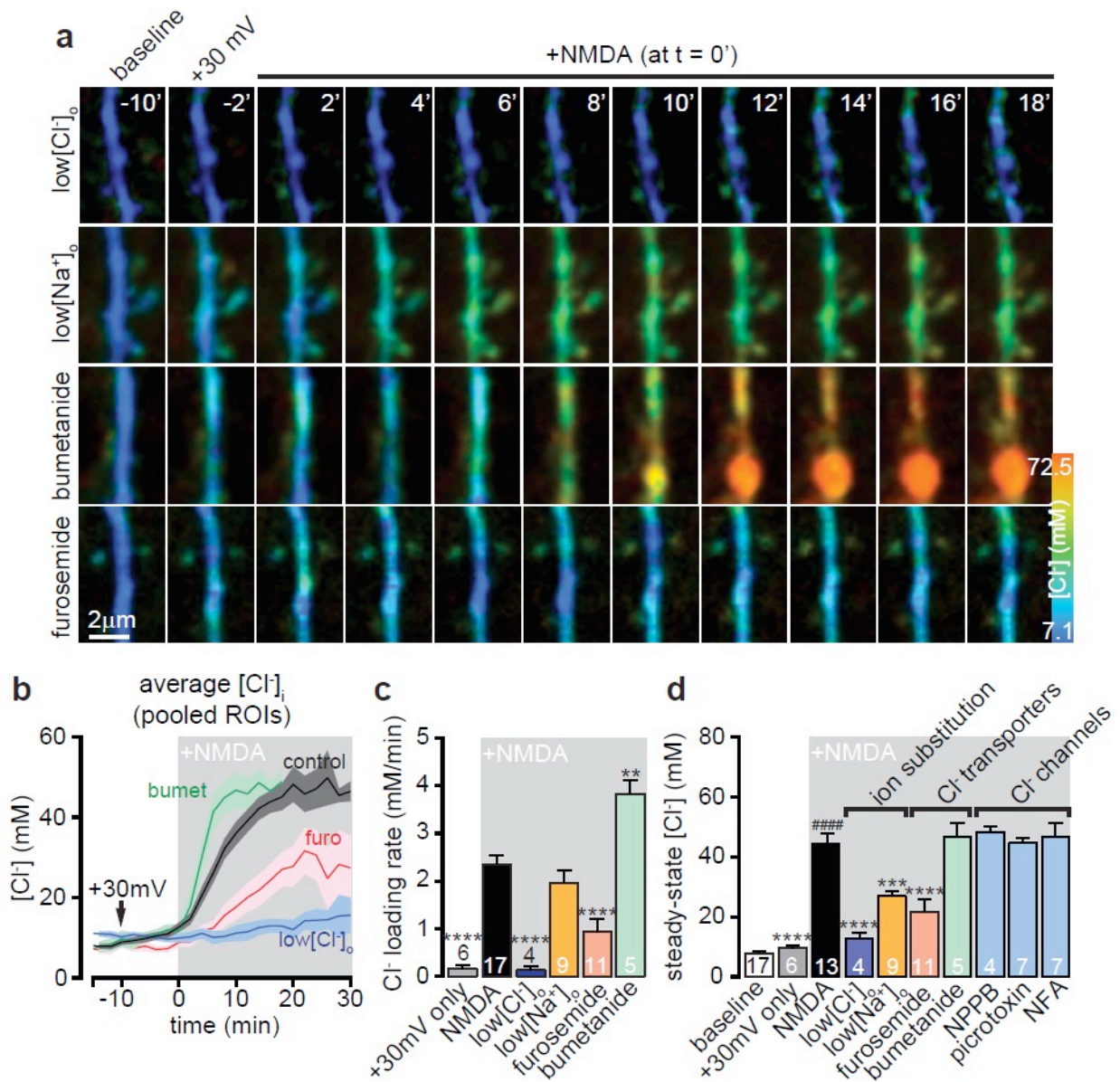

Figure 7. NMDA-induced $\mathrm{Cl}^{-}$influx and blebbing is $\mathrm{KCC} 2$ dependent. a) Example MQAEFLIM time-lapses of NMDA-induced blebbing in low $\left[\mathrm{Cl}^{-}\right]_{\mathrm{o}}$, low $\left[\mathrm{Na}^{+}\right]_{\mathrm{o}}$, bumetanide, and furosemide conditions. NMDA $(20 \mu \mathrm{M})$ was continually applied at time $=0 \mathrm{~min}$. b) Average $M Q A E-\left[\mathrm{Cl}^{-}\right]_{\mathrm{i}}$ readouts over time for datasets outlined in 'a'. Data are pooled ROI averages (i.e. encompassing blebbed and non-blebbed ROIs). c) Average $\mathrm{Cl}^{-}$loading rate, calculated from the rising slope of NMDA-induced $\mathrm{Cl}^{-}$increase from ' $\mathrm{b}$ '. $+30 \mathrm{mV}$ only indicates continuous depolarization for $40 \mathrm{~min}$. ${ }^{* * * *} \mathrm{P}<0.0001$ for NMDA alone compared to $+30 \mathrm{mV},\left[\mathrm{Cl}^{-}\right]_{\mathrm{o}}$, and furosemide conditions, ${ }^{*} * \mathrm{P}=0.0032$ compared to bumetanide, one-way ANOVA with Tukey test. d) Quantitative summary of steady-state $M Q A E-\left[\mathrm{Cl}^{-}\right]_{\mathrm{i}}$ at $15 \mathrm{~min}$ post NMDA application.

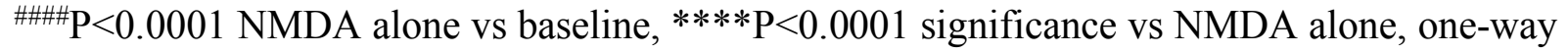
ANOVA with Tukey test. 
Legends for movies 1, 2 and 3 that provide time lapse illustrations for data in Figure 7:

\section{3}

Movie 1: NMDA triggers dendritic [Cl-]i loading and blebbing. Time lapse of MQAE-FLIM images to measure spatiotemporal changes in dendritic [Cl-]i. NMDA $(20 \mu \mathrm{m})$ application occurs at '+NMDA' tag and is immediately followed by dramatic and localized increases in $[\mathrm{Cl}-]_{\mathrm{i}}$ that form dendritic blebs.

Movie 2: Dendritic blebbing requires Cl- influx. Application of NMDA (20 $\mu \mathrm{m})$ does not generate substantial subcellular increases in low [Cl-]o conditions and dendritic blebbing does not occur, indicating that dendritic NMDA-induced blebbing requires $\mathrm{Cl}$ - influx.

\section{Movie 3: Blocking KCC2 with furosemide reduces NMDA-induced Cl- influx and}

blebbing. Bath pre-application of furosemide $(200 \mu \mathrm{M})$ dramatically reduced $\mathrm{Cl}$ - loading and

blebbing in the presence of NMDA $(20 \mu \mathrm{m})$, indicating that $\mathrm{KCC} 2$ transport direction is reversed in cytotoxic edema. 


\section{Discussion}

Early observations of subcellular $\left[\mathrm{Cl}^{-}\right]_{\mathrm{i}}$ heterogeneities using electrophysiology (Alger and Nicoll, 1979; Barker and Ransom, 1978; Nicoll et al., 1976) have been corroborated by recent studies employing ratiometric sensors (Berglund et al., 2006; Glykys et al., 2014; Kuner and Augustine, 2000; Sulis Sato et al., 2017), however our understanding of the spatial regulation and functional impact of these microdomains is limited. Here we demonstrate that pairing MQAE-FLIM with electrophysiology allowed us to provide the first high resolution quantitative measurements of the spatiotemporal $\left[\mathrm{Cl}^{-}\right]_{\mathrm{i}}$ dynamics throughout cortical pyramidal dendrites. MQAE-FLIM had both the sensitivity and dynamic range to measure equilibrative $\left[\mathrm{Cl}^{-}\right]_{\mathrm{i}}$ changes under resting conditions and cytotoxic changes during intense NMDA receptor stimulation. We quantified the basal contributions of $\mathrm{NKCC} 1$ and $\mathrm{KCC} 2$ in maintaining $\left[\mathrm{Cl}^{-}\right]_{\mathrm{i}}$ at rest as well as modest changes in dendritic $\left[\mathrm{Cl}^{-}\right]_{\mathrm{i}}$ incurred by membrane depolarization. Importantly, we report that NMDA-induced cytotoxic swelling is driven by $\mathrm{Cl}^{-}$influx via $\mathrm{KCC} 2$ reversed transport. Our observations lead to the surprising conclusion that discrete microdomains of high $\left[\mathrm{Cl}^{-}\right]_{i}$ can be generated with sharp boundaries that give rise to dendritic blebbing. Quantifying dendritic $\mathrm{Cl}^{-}$dynamics and spatial distributions have been longstanding challenges. This is due to the robust homeostatic control of $\mathrm{Cl}^{-}$gradients, as well as the bidirectional nature of $\mathrm{Cl}^{-}$flux that depends on dynamic $E_{m}$ and $E_{C l-}$ values (Arosio and Ratto, 2014). Additionally $\mathrm{Cl}^{-}$imaging using many genetically encoded fluorescent proteins is problematic due to $\mathrm{pH}$ sensitivity, but also non-uniform distortions caused by the optical properties of brain tissue that alter even ratiometric excitation and emission values (Oheim et al., 2001; Sulis Sato et al., 2017). This is further complicated by volume changes that occur in parallel with $\left[\mathrm{Cl}^{-}\right]$, which can affect intrinsic optical properties of the tissue and thereby 
501 subsequent intensity changes. Two recent studies show substantial improvements in this area

502 using dual ratiometric $\mathrm{Cl}^{-}-\mathrm{pH}$ sensors such as ClopHensorN and LSSmClopHesnsor (Mukhtarov

503 et al., 2013; Sulis Sato et al., 2017). However MQAE-FLIM is still preferable for quantitative

504 studies due to its high $\mathrm{Cl}^{-}$affinity, fast detection kinetics, insensitivity to changes in emission

505 intensity, dye concentration, photobleaching, and light scattering (Arosio and Ratto, 2014;

506 Fukuda et al., 1998; Kovalchuk and Garaschuk, 2012; Marandi et al., 2002; Verkman et al.,

507 1989). MQAE is also relatively insensitive to $\mathrm{pH}$ fluctuations (Koncz and Daugirdas, 1994) and

508 viscosity (Kaneko et al., 2002). In support of this, we observed a near-complete inhibition of

509 NMDA-induced rises in $M Q A E-\left[\mathrm{Cl}^{-}\right]_{\mathrm{i}}$ in low $\left[\mathrm{Cl}^{-}\right]_{\mathrm{o}}$, even though NMDA triggers cytosolic

510 acidification (Canzoniero et al., 1996). One limitation for imaging MQAE is nonspecific but

511 modest quenching by gluconate, EGTA and HEPES (but notably not by endogenous anions such

512 as $\mathrm{SO}_{4}{ }^{2-}, \mathrm{HCO}_{3}{ }^{-}$, and $\left.\mathrm{PO}_{4}{ }^{3-}\right)($ Kaneko et al., 2002; Kovalchuk and Garaschuk, 2012). This is

513 typically controlled for by calibrating the dye in situ, although complete $\left[\mathrm{Cl}^{-}\right]_{\mathrm{i}}:\left[\mathrm{Cl}^{-}\right]_{\mathrm{o}}$

514 equilibration is difficult to achieve. Indeed, our measured $\mathrm{K}_{\mathrm{Sv}}$ for in situ $\left(6.53 \mathrm{M}^{-1}\right)$ and in vitro

$515\left(20.19 \mathrm{M}^{-1}\right)$ calibrations were both within the range of in situ experiments from another group (5-

$\left.51620 \mathrm{M}^{-1}\right)\left(\right.$ Kaneko et al., 2004) and well below MQAE in distilled water $\left(185 \mathrm{M}^{-1}\right)$. It is therefore

517 beneficial to patch load MQAE, as these unspecific anion interactions can be controlled for by

518 their inclusion in calibration solutions.

Notwithstanding the challenges and considerations associated with lifetime imaging, our

520 MQAE-FLIM readouts from bulk- and pipette-loaded configurations are in agreement with each

521 other and with basal $\left[\mathrm{Cl}^{-}\right]_{\mathrm{i}}$ values predicted in the literature (Delpire and Staley, 2014; Kuner and

522 Augustine, 2000; Staley and Proctor, 1999). An important validation of our approach is its

523 accuracy compared to regional $E_{G A B A}$ measures. $M Q A E-\left[\mathrm{Cl}^{-}\right]_{\mathrm{i}}$ readouts were $<10 \mathrm{mM}$ below 
$524 E_{G A B A^{-}}\left[\mathrm{Cl}^{-}\right]_{\mathrm{i}}$, which we attribute to a combination of $\mathrm{GABA}_{\mathrm{A}} \mathrm{R} \mathrm{HCO}_{3}{ }^{-}$efflux (Kaila, 1994) and 525 imperfect voltage clamp due to $\mathrm{K}^{+}$leak in the absence of $\mathrm{K}^{+}$channel blockers. Nevertheless, the 526 variance in both our $M Q A E-\left[\mathrm{Cl}^{-}\right]_{\mathrm{i}}$ and $E_{G A B A}-\left[\mathrm{Cl}^{-}\right] \mathrm{i}$ values were strongly correlated, and 527 commensurate with the physiological heterogeneity in $\left[\mathrm{Cl}^{-}\right]_{\mathrm{i}}$ reported by other groups (Barker and Ransom, 1978; Delpire and Staley, 2014; Glykys et al., 2014; Khirug et al., 2008; Kuner and

529 Augustine, 2000; Sulis Sato et al., 2017). There was also no detectable impact of $\mathrm{Br}^{-}$ion flux 530 either $M Q A E-\left[\mathrm{Cl}^{-}\right]_{\mathrm{i}}$, meaning MQAE-Br could be used over a broad concentration range 531 depending on experimental requirements. The stability of $M Q A E-\left[\mathrm{Cl}^{-}\right]_{\mathrm{i}}$ over a 60 min recording indicates that quenching from endogenous and exogenously (pipette) supplied anion species was minimal relative to $\mathrm{Cl}^{-}$. Thus, the variability of $\left[\mathrm{Cl}^{-}\right]_{\mathrm{i}}$ we observe within neuronal dendrites

534 highlights the clear need for quantitative evaluations of the functional implications of $\mathrm{Cl}^{-}$ 535 microdomains.

The temporal dynamics of $\mathrm{Cl}^{-}$handling has been shown to be modified over time scales

537 of days (during development), minutes (KCC2 posttranslational regulation by calpains or

538 WNK/SPAK), and milliseconds-seconds (ionic plasticity, shunting) (Alessi et al., 2014; Doyon 539 et al., 2016; Kaila et al., 2014). With MQAE-FLIM we quantified transport capacity of NKCC1 540 and KCC2 over time but also at multiple subcellular sites. For example, patched neurons and 541 astrocytes defended their respective low $(<10 \mathrm{mM})$ and high $(15-20 \mathrm{mM})\left[\mathrm{Cl}^{-}\right]_{\mathrm{i}}$ setpoints when 542 dialyzed with mismatched $\mathrm{Cl}^{-}$loads. Interestingly, we observed regional variance in $\mathrm{Cl}^{-}$export 543 in both cell types, with higher transport efficiency in dendrites and fine processes. MQAE-FLIM 544 also enabled us to measure a wide range of $\left[\mathrm{Cl}^{-}\right]_{\mathrm{i}}$ changes. By blocking $\mathrm{KCC} 2$ or $\mathrm{NKCC} 1$ in 545 dendrites with either furosemide or bumetanide, we could quantify subtle $(<5 \mathrm{mM})$ changes in $546 \mathrm{Cl}^{-}$transport at rest with basal synaptic transmission intact. Detection of such modest $\left[\mathrm{Cl}^{-}\right]_{\mathrm{i}}$ 
547 variations is testament to the sensitivity and practicability of MQAE-FLIM, as millimolar

548 changes would affect excitability (Doyon et al., 2016). We also measured large $\left[\mathrm{Cl}^{-}\right]_{\mathrm{i}}$ changes in

549 neurons loaded with $\left[\mathrm{Cl}^{-}\right]_{\text {pipette }}=80 \mathrm{mM}$, where somatic and dendritic was reduced typically

550 below $40 \mathrm{mM}$ in part by export via $\mathrm{KCC} 2$. This allowed us to also quantify the impact of KCC2

551 dephosphorylation in T906A/T1007A mice (Friedel et al., 2015; Heubl et al., 2017; Moore et al.,

552 2018; Pisella et al., 2019; Watanabe et al., 2019), where $\left[\mathrm{Cl}^{-}\right]_{\mathrm{i}}$ was maintained at near-control

553 levels despite an elevated $\left[\mathrm{Cl}^{-}\right]_{\text {pipette }}$ load $(80 \mathrm{mM})$. Indeed, there is growing appreciation for

554 dynamic KCC2 phosphorylation, for example in establishing excitatory GABAergic tone during

555 development, impacting cognitive function, and susceptibility to epileptiform activity (Friedel et

556 al., 2015; Moore et al., 2019; Moore et al., 2018; Pisella et al., 2019; Silayeva et al., 2015;

557 Watanabe et al., 2019).

Evidence of spatial $\left[\mathrm{Cl}^{-}\right]_{\mathrm{i}}$ heterogeneity within cellular subcompartments in previous

559 studies (Barker and Ransom, 1978; Berglund et al., 2006; Glykys et al., 2014; Khirug et al.,

560 2008; Kuner and Augustine, 2000) suggested that standing $\mathrm{Cl}^{-}$gradients could exist within

561 cytoplasmic domains of neurons. Our observations of inhomogeneous $\left[\mathrm{Cl}^{-}\right]_{\mathrm{i}}$ distributions in

562 dendrites at rest and the dramatic induction of discrete $\left[\mathrm{Cl}^{-}\right]_{\mathrm{i}}$ microdomains that lead to dendritic

563 blebs with distinct edges indicates that $\mathrm{Cl}^{-}$mobility can be spatially restricted. Although

564 controversial (Kaila et al., 2014), the suggestion that $\mathrm{Cl}^{-}$ions are diffusion-limited, even at rest,

565 has been proposed to occur due to a nonuniform distribution of immobile intracellular and

566 extracellular anions [(Glykys et al., 2014) see also co-submission by Rahmati et al., 2020]. While

567 our data cannot confirm the role of immobile anions in setting $\mathrm{Cl}^{-}$microdomains, the uneven

568 distribution cytosolic proteins (Gut et al., 2018) could give rise to compensatory heterogeneities

569 in mobile $\mathrm{Cl}^{-}$ions. In cytotoxic edema, breakdown of negatively charged proteins and structural 
actin is well established in excitotoxicity (Halpain et al., 1998; Lipton, 1999) and would likely affect $\mathrm{Cl}^{-}$mobility in dendrites (Glykys et al., 2014). The possibility of $\mathrm{Cl}^{-}$microdomains might be expected in some dendritic regions given that dendritic morphology alone can affect ion diffusion. For instance, the thin necks of synaptic spines can restrict $\mathrm{Ca}^{2+}$ diffusion and propagation of electrical potentials between spine heads and dendrites (Kwon et al., 2017; Yuste and Denk, 1995). Additionally, recent modelling studies predict that longitudinal $\mathrm{Cl}^{-}$diffusion in dendrites is restricted by the distribution and strength of $\mathrm{K}^{+}-\mathrm{Cl}^{-}$cotransporters (Doyon et al., 2011), by tortuosity imposed spines (Mohapatra et al., 2016), and even by passive membrane properties (Lombardi et al., 2019), all of which could affect local GABAergic inhibition and ionic plasticity. Given that little is known about $\mathrm{Cl}^{-}$microdomains and their regulation at the sub-dendritic level, future studies using MQAE-FLIM will be fundamental to understanding KCC2's vital role in synaptic physiology.

The data presented here indicate that formation of pathological blebs requires reversed $\mathrm{KCC} 2$ transport that generates microdomains of high dendritic $\left[\mathrm{Cl}^{-}\right]_{\mathrm{i}}$. Quantitative readouts of dendritic $\left[\mathrm{Cl}^{-}\right]_{\mathrm{i}}$ revealed spatially discrete increases in $\mathrm{Cl}^{-}$that were blocked by furosemide, leading to our conclusion that $\mathrm{KCC} 2$ drives $\mathrm{Cl}^{-}$import into blebs. We also observed a surprising increase in $\mathrm{Cl}^{-}$loading rate when $\mathrm{NKCC} 1$ was blocked with bumetanide, indicating that $\mathrm{NKCC} 1$ was also pumping in reverse mode (i.e. $\mathrm{Cl}^{-}$export) which has been suggested to occur when $\mathrm{Na}^{+}$, $\mathrm{K}^{+}$, and $\mathrm{Cl}^{-}$concentration gradients are dramatically altered (Brumback and Staley, 2008; Glykys et al., 2017; Kaila et al., 2014). KCC2 transport direction depends on the outwardly-directed K+ gradient but also the stoichiometry of $\mathrm{K}^{+}: \mathrm{Cl}^{-}$ions (Payne, 1997). In silico and in vitro experiments on KCC2 thermodynamic driving force have shown $\mathrm{K}^{+} / \mathrm{Cl}^{-}$cotransport can reverse when $\left[\mathrm{K}^{+}\right]_{\mathrm{o}}$ increases beyond $5 \mathrm{mM}$ (DeFazio et al., 2000; Payne, 1997). Reversed transport is 
593 therefore likely to occur in excitoxicity/stroke, where $\left[\mathrm{K}^{+}\right]_{\mathrm{o}}$ increases to $>60 \mathrm{mM}$ (Hansen and

594 Nedergaard, 1988; Rossi et al., 2007). A recent study showed that brief ischemia induced

595 prolonged $(>1 \mathrm{hr})$ increases in neuronal $\left[\mathrm{Cl}^{-}\right]_{\mathrm{i}}$ and epileptiform activity that were sensitive to

596 furosemide block (Blauwblomme et al., 2018). Further, the frequently observed decrease in

597 KCC2 expression in neurotraumas (Coull et al., 2003; Jaenisch et al., 2010; Kaila et al., 2014;

598 Zhou et al., 2012) could be explained by the present findings as a protective adaptation to

599 minimize pathological $\mathrm{Cl}^{-}$loading in neurons. In conclusion, our joint MQAE-FLIM and

600 electrophysiology approach has provided valuable insights into the tight spatiotemporal

601 regulation of $\left[\mathrm{Cl}^{-}\right]_{\mathrm{i}}$ microdomains as it relates to integration of synaptic currents, but also in

602 neuropathologies where perturbed $\mathrm{Cl}^{-}$handling can degrade inhibitory tone in epilepsy or trigger

603 dendritic swelling in cerebral edema (Cohen et al., 2002; Rungta et al., 2015).

604

605 Methods

606 Animals

607

All animal care protocols were approved by the University of British Columbia's Animal

608 Care Committee in accordance with the Canadian Council on Animal Care guidelines. Acute

609 slice experiments from rat were performed on postnatal day $(\mathrm{P})>25$ Sprague Dawley rats

610 (Charles River). Mouse experiments were performed on $\mathrm{P}>25 \mathrm{KCC}^{\mathrm{AA}}$ (homozygous) or

$611 \mathrm{KCC} 2^{\mathrm{WT}}$ animals. All animals were housed on a 12/12hr light/dark cycle with at least one cage

612 mate and ad libidum access to laboratory chow and water.

\section{Acute Cortical Slice Preparation}


Rats were anaesthetized by isoflourane inhalation in air and decapitated. The brain was quickly extracted, blocked, and mounted on a vibrating slicer (Leica VT1200S) while submerged

616 in an ice-cold solution consisting of (in mM): $120 \mathrm{NMDG}, 2.5 \mathrm{KCl}, 25 \mathrm{NaHCO}_{3}, 1 \mathrm{CaCl}_{2}, 7$

$617 \mathrm{MgCl}_{2}, 1.25 \mathrm{NaH}_{2} \mathrm{PO}_{4}, 20$ glucose, 2.4 Na-pyruvate, $1.3 \mathrm{Na}$-ascorbate and saturated with $95 \%$

$618 \mathrm{O}_{2} / 5 \% \mathrm{CO}_{2}$. Transverse cortical slices were cut $(370 \mu \mathrm{m})$ and transferred into a chamber

619 containing artificial cerebral spinal fluid $(\mathrm{aCSF})$ at $33^{\circ} \mathrm{C}$ for at least one hour prior to

620 experimentation. aCSF consisted of $126 \mathrm{mM} \mathrm{NaCl}, 26 \mathrm{mM} \mathrm{NaHCO}_{3}, 2.5 \mathrm{mM} \mathrm{KCl}, 1.25 \mathrm{mM}$

$621 \mathrm{NaH}_{2} \mathrm{PO}_{4}, 2 \mathrm{mM} \mathrm{MgCl}, 2 \mathrm{mM} \mathrm{CaCl}_{2}$, and $10 \mathrm{mM}$ glucose and was continuously bubbled with $62295 \% \mathrm{O}_{2} / 5 \% \mathrm{CO}_{2}$.

\section{Chemicals and Reagents}

629 were made into aliquots dissolved in water or DMSO and diluted to the final concentration in

630 aCSF or intracellular recording solution - the final concentration of DMSO never exceeded

$6310.1 \%$.

\section{Electrophysiology}

After stabilization, slices were carefully transferred to a recording chamber continually

634 perfused with aCSF $\left(33^{\circ} \mathrm{C}\right.$, stage heater from Luigs \& Neumann) at a rate of $1-2 \mathrm{~mL} / \mathrm{min}$. Layer

$6354 / 5$ pyramidal neurons in the cortex were identified using widefield infrared (IR) illumination 
and captured with an IR-1000 (DAGE-MTI) camera fitted on a LSM 7MP 2-photon imaging system (Zeiss). Whole-cell patch clamp recordings were obtained using thin-walled borosilicate glass microelectrodes (Warner) pulled to a tip resistance of 3-5 M $\Omega$ pulled using a P-97 Flaming/Brown Micropipette Puller (Sutter Instrument). Electrodes were filled with an intracellular recording solution containing (in $\mathrm{mM}$ ): $108 \mathrm{~K}$-Gluconate, $3 \mathrm{KCl}, 2 \mathrm{MgCl}_{2}, 8 \mathrm{Na}$ Gluconate, $1 \mathrm{~K}_{2}$-EGTA, $0.23 \mathrm{CaCl}_{2}$, 0.05 Alexa-594, 6-8 MQAE, $4 \mathrm{~K}_{2}$-ATP and $0.3 \mathrm{Na}_{3}$-GTP at pH 7.25 with 10 HEPES. 15 minutes was allotted for intracellular equilibration for all experiments unless otherwise indicated. Recordings were made using a MultiClamp 700B amplifier and Digidata 1440A digitiser (Axon Instruments, Molecular Devices) controlled via Clampex 10.7 acquisition software. Cells were voltage clamped at -60 mV unless specified otherwise. Access resistance was always $<20 \mathrm{M} \Omega$, and cells with holding currents below -100 pA after break-in were discarded.

\section{Time-Resolved 2-photon fluorescent lifetime imaging setup}

All experiments were performed on a LSM 7MP 2-photon imaging system from Zeiss fitted with a SPC-150 FLIM acquisition module from Becker \& Hickl. Femtosecond excitation was achieved with a Ti:Sapphire Chameleon Ultra II 2-photon laser (Coherent) pulsing at $80 \mathrm{MHz}$ and tuned to $750 \mathrm{~nm}$. Laser pulse timing was collected directly from the laser's internal photodiode. Images were acquired with a Zeiss 20X-W/1.0 NA objective at digital zooms ranging from $3 \mathrm{x}-12 \mathrm{x}$ at $256 \mathrm{x} 256$ or $128 \times 128$ pixel resolutions depending on zoom factor. Emission light was first passed through an IR filter (700nm shortpass) to block spurious excitation light, then split with a 480nm longpass dichroic mirror (Chroma tech). Blue MQAE fluorescence was then filtered with a 460/50nm bandpass filter and collected with a GaAsP hybrid detector (HPM-100-40 hybrid PMT, Becker and Hickl). After the 480nm beam splitter, 
659

660

661

662

663

664

665

666

667

668

669

670

671 (see 'Electrophysiology') including Alexa-594. The desired $\mathrm{Cl}^{-}$concentration was achieved by

672 adjusting the concentration of $\mathrm{KCl}$ and was balanced by equimolar $\mathrm{K}$-gluconate. For $2.5 \mathrm{mM}\left[\mathrm{Cl}^{-}\right.$

673 ], some $\mathrm{MgCl}_{2}$ was substituted with $\mathrm{MgSO}_{4}$, as MQAE fluorescence is not quenched by $\mathrm{SO}_{4}{ }^{2-}$

674 anions (Kaneko et al., 2002). The calibration solution was placed in a sealed micropipette and

675 imaged in warmed $\left(33^{\circ} \mathrm{C}\right) \mathrm{aCSF}$ under the microscope using consistent experimental parameters

676 as in situ. Calibration data were fit in GraphPad Prism 6 with a one-phase exponential decay 677 curve to match the monoexponential decay parameters of MQAE lifetime:

678

red emission from Alexa-594 was passed through a 630/75nm bandpass filter (Chroma) before detection with a LSM BiG GaAsP photomultiplier (Zeiss).

\section{MQAE-FLIM Calibrations}

In situ calibrations were conducted as previously described (Gensch et al., 2015; Kovalchuk and Garaschuk, 2012) to measure $\left[\mathrm{Cl}^{-}\right]_{\mathrm{i}}$ in neurons and astrocytes bulk loaded with MQAE. Briefly, acute transverse hippocampal/cortical slices were incubated in $6 \mathrm{mM}$ MQAE for $20 \mathrm{~min}$ at 33$34^{\circ} \mathrm{C}$. Slices were then transferred to the imaging chamber containing the $\mathrm{Cl}^{-} / \mathrm{OH}^{-}$antiporter tributyltin and the $\mathrm{K}^{+} / \mathrm{H}^{+}$ionophore nigericin in a $0-40 \mathrm{mM} \mathrm{KCl}$ solution also containing $10 \mathrm{mM}$ HEPES, $10 \mathrm{mM}$ Na-Gluconate, $\mathrm{pH}$ balanced to 7.35 with $\mathrm{KOH}$, osmolarity adjusted to 300 with K-Gluconate, and warmed to $33^{\circ} \mathrm{C}$.

In vitro MQAE calibrations were performed to match the recording conditions in whole-cell patch clamp experiments. Calibration solutions exactly mimicked the internal recording solution

$$
Y=\left(Y_{o}-A\right) e^{-K * X}+A
$$


679 Where $\mathrm{Y}=$ measured lifetime (in ps), $\mathrm{X}=\left[\mathrm{Cl}^{-}\right], \mathrm{Y}_{\mathrm{o}}=$ lifetime at $0\left[\mathrm{Cl}^{-}\right]$(in ps), $\mathrm{A}=$ lifetime horizontal asymptote at high $\left[\mathrm{Cl}^{-}\right]$(in ps), $\mathrm{K}=$ rate constant. Our best-fit line calculated from

681

682

683

684

685

686

687

688

689

690

691

692

693

694

695

696

697

698

699

pooled averages was:

$$
Y=(4139-1247) e^{-0.02902 * X}+1247
$$

Due to the limitations of the curve fit, any measured lifetime values that were above the upper limit of 4139 ps were set to $0 \mathrm{mM}\left[\mathrm{Cl}^{-}\right]$. The $K_{d}$ value for $\mathrm{Cl}^{-}$-dependent MQAE quenching was calculated as $K_{d}=0.69 / \mathrm{K}$.

\section{Fluorescent Lifetime Imaging and Data Analysis}

For bulk loaded imaging, slices were loaded with MQAE (6 mM) as described above. Neuronal somata were identified visually, and astrocytes were identified by SR101 stain $(1 \mu \mathrm{M}$, post-slice incubation) or visually in unstained tissue. Images were acquired by continual XY frame scanning over $15 \mathrm{~s}-60 \mathrm{~s}$ to ensure adequate photon counts for accurate lifetime curve-fitting at low laser power. All cells were imaged between $50-100 \mu \mathrm{m}$ below the slice surface to balance minimal fluorescent scattering and maximal cell viability. For patch loaded imaging, cells were dialyzed with internal solution containing $6 \mathrm{mM}$ MQAE for a least $15 \mathrm{~min}$ prior to imaging to allow for complete equilibration of dye and pipette salts.

Lifetime data were collected in parallel to signal intensity for each pixel and analysed, and the intensity data were used to process lifetime data and for illustration purposes. Lifetime data were processed using SPCImage 7.3 software from Becker \& Hickl and decay values of each pixel were calculated based on a monoexponential fit described above. A bin factor of 1 was used to attain a photon count $\geq 10$ at the tail ( $9 \mathrm{~ns}$ after laser pulse) and a $\chi^{2}$ fit value close to 1 . Lifetime 
decay matrices were decimated from 32 bit to 16 bit by rounding values to the nearest 1 ps in MATLAB (Mathworks). Intensity images were used as a registration template to align the lifetime images in MATLAB, and dendritic lifetime signals were measured in ImageJ. For dendritic recordings, ROIs were mapped on intensity images to ensure signal measurements were in-focus and transferred to the lifetime image. All colour-coded example FLIM images in the figures are intensity-weighted RGB images for ease of visualisation of MQAE signal over background fluorescence.

\section{Rubi-GABA uncaging}

Rubi-GABA (Rial Verde et al., 2008) was purchased from Tocris and dissolved directly into recording aCSF at $0.5 \mathrm{mM}$ and stored as frozen aliquots prior to use. The Rubi-GABA solution was always protected from ambient light, during preparation and experimentation. Rubi-GABA was locally puff-ejected near the patched neuron $(\sim 100 \mu \mathrm{m})$ and held at a constant pressure of 1 psi throughout the experiment. Somatic MQAE-FLIM measures were then taken with the 2photon laser tuned to $750 \mathrm{~nm}$ and imaged at low power $(<4 \mathrm{~mW})$ to prevent GABA uncaging during the acquisition. The laser was then tuned to $800 \mathrm{~nm}$ for Rubi-GABA photolysis, and uncaging laser power was slowly increased until reliable $\mathrm{GABA}_{\mathrm{A}}$ receptor currents were observed at $V_{m}=-80 \mathrm{mV}$ (50 ms pulses). Patched neurons were filled with $8 \mathrm{mM}$ MQAE in 80 $\mathrm{mM} \mathrm{Cl}^{-}$intracellular recording solution, and $0.5 \mu \mathrm{M}$ TTX was included in normal aCSF to block voltage-gated $\mathrm{Na}^{+}$channels. A liquid junction potential of $6 \mathrm{mV}$ was applied to all voltage steps. $E_{G A B A}\left[\mathrm{Cl}^{-}\right]_{\mathrm{i}}$ was calculated from $E_{G A B A}$ using the Nernst Equation.

\section{Dendritic blebbing assay}


721 To isolate swelling in a single cell we used a high $\mathrm{Mg}^{2+}(6 \mathrm{mM})$ aCSF solution to increase the

722 likelihood of voltage-dependent $\mathrm{Mg}^{2+}$ block of tissue-wide NMDA receptors as previously

723 described (Dissing-Olesen et al., 2014). Layer 4/5 cortical neurons were whole-cell patch

724 clamped with MQAE in a K-gluconate internal solution described above and held at $V_{m}=-60$

$725 \mathrm{mV}$. Cells were dialyzed for a 10-20 min baseline period prior to imaging, followed by a $10 \mathrm{~min}$

726 depolarization to $V_{m}=+30 \mathrm{mV}$ to ensure complete unblock NMDA receptors in dendrites and

727 accommodate loss of membrane potential control from space clamp issues. Sustained bath

728 application of $20 \mu \mathrm{M}$ NMDA and $10 \mu \mathrm{M}$ glycine was used to trigger $\mathrm{Cl}^{-}$loading and swelling.

729 Low $\left[\mathrm{Cl}^{-}\right]_{\mathrm{o}}$ aCSF was made my replacing $\mathrm{NaCl}$ with equimolar Na-Gluconate, and low $\left[\mathrm{Na}^{+}\right]_{\mathrm{o}}$

730 aCSF by replacing $\mathrm{NaCl}$ with $\mathrm{NMDG}^{+}$and $\mathrm{pH}$ balanced with $\mathrm{HCl}$. Apical dendrites were

731 selected for imaging based on their proximity to the soma for voltage clamp $(<100 \mu \mathrm{m})$, and

732 images were acquired over 20-30s, typically 160 frames, every 2 min to minimize phototoxicity.

\section{Acknowledgements} and K.K. designed the study with B.A.M., and B.A.M. supervised the study.

\section{References}

739 Alessi, D.R., Zhang, J., Khanna, A., Hochdorfer, T., Shang, Y., and Kahle, K.T. (2014). The WNK-

740 SPAK/OSR1 pathway: master regulator of cation-chloride cotransporters. Sci Signal 7, re3.

741 Alger, B.E., and Nicoll, R.A. (1979). GABA-mediated biphasic inhibitory responses in hippocampus.

742 Nature 281, 315-317.

743 Allen, N.J., Rossi, D.J., and Attwell, D. (2004). Sequential release of GABA by exocytosis and reversed

744 uptake leads to neuronal swelling in simulated ischemia of hippocampal slices. J Neurosci 24, 3837-3849. 
Arosio, D., Garau, G., Ricci, F., Marchetti, L., Bizzarri, R., Nifosi, R., and Beltram, F. (2007). Spectroscopic and structural study of proton and halide ion cooperative binding to gfp. Biophysical journal 93, 232-244.

Arosio, D., and Ratto, G.M. (2014). Twenty years of fluorescence imaging of intracellular chloride. Frontiers in cellular neuroscience $8,258$.

Barker, J.L., and Ransom, B.R. (1978). Amino acid pharmacology of mammalian central neurones grown in tissue culture. J Physiol 280, 331-354.

Berglund, K., Schleich, W., Krieger, P., Loo, L.S., Wang, D., Cant, N.B., Feng, G., Augustine, G.J., and Kuner, T. (2006). Imaging synaptic inhibition in transgenic mice expressing the chloride indicator, Clomeleon. Brain cell biology 35, 207-228.

Blaesse, P., Airaksinen, M.S., Rivera, C., and Kaila, K. (2009). Cation-chloride cotransporters and neuronal function. Neuron 61, 820-838.

Blauwblomme, T., Dzhala, V., and Staley, K. (2018). Transient ischemia facilitates neuronal chloride accumulation and severity of seizures. Annals of clinical and translational neurology 5, 1048-1061. Bormann, J., Hamill, O.P., and Sakmann, B. (1987). Mechanism of anion permeation through channels gated by glycine and gamma-aminobutyric acid in mouse cultured spinal neurones. J Physiol 385, 243286.

Brumback, A.C., and Staley, K.J. (2008). Thermodynamic regulation of NKCC1-mediated Clcotransport underlies plasticity of GABA(A) signaling in neonatal neurons. J Neurosci 28, 1301-1312. Canzoniero, L.M., Sensi, S.L., and Choi, D.W. (1996). Recovery from NMDA-induced intracellular acidification is delayed and dependent on extracellular bicarbonate. The American journal of physiology 270, C593-599.

Chen, L.C., Lloyd, W.R., 3rd, Chang, C.W., Sud, D., and Mycek, M.A. (2013). Fluorescence lifetime imaging microscopy for quantitative biological imaging. Methods in cell biology 114, 457-488. Chevy, Q., Heubl, M., Goutierre, M., Backer, S., Moutkine, I., Eugene, E., Bloch-Gallego, E., Levi, S., and Poncer, J.C. (2015). KCC2 Gates Activity-Driven AMPA Receptor Traffic through Cofilin Phosphorylation. J Neurosci 35, 15772-15786.

Cohen, I., Navarro, V., Clemenceau, S., Baulac, M., and Miles, R. (2002). On the origin of interictal activity in human temporal lobe epilepsy in vitro. Science 298, 1418-1421.

Cordero-Erausquin, M., Coull, J.A., Boudreau, D., Rolland, M., and De Koninck, Y. (2005). Differential maturation of GABA action and anion reversal potential in spinal lamina I neurons: impact of chloride extrusion capacity. J Neurosci 25, 9613-9623.

Coull, J.A., Boudreau, D., Bachand, K., Prescott, S.A., Nault, F., Sik, A., De Koninck, P., and De Koninck, Y. (2003). Trans-synaptic shift in anion gradient in spinal lamina I neurons as a mechanism of neuropathic pain. Nature 424, 938-942.

DeFazio, R.A., Keros, S., Quick, M.W., and Hablitz, J.J. (2000). Potassium-coupled chloride cotransport controls intracellular chloride in rat neocortical pyramidal neurons. J Neurosci 20, 8069-8076.

Delpire, E., and Staley, K.J. (2014). Novel determinants of the neuronal Cl- concentration. J Physiol 592, 4099-4114.

Dissing-Olesen, L., LeDue, J.M., Rungta, R.L., Hefendehl, J.K., Choi, H.B., and MacVicar, B.A. (2014). Activation of neuronal NMDA receptors triggers transient ATP-mediated microglial process outgrowth. J Neurosci 34, 10511-10527.

Doyon, N., Prescott, S.A., Castonguay, A., Godin, A.G., Kroger, H., and De Koninck, Y. (2011). Efficacy of synaptic inhibition depends on multiple, dynamically interacting mechanisms implicated in chloride homeostasis. PLoS computational biology 7, e1002149.

Doyon, N., Vinay, L., Prescott, S.A., and De Koninck, Y. (2016). Chloride Regulation: A Dynamic Equilibrium Crucial for Synaptic Inhibition. Neuron 89, 1157-1172.

Friedel, P., Kahle, K.T., Zhang, J., Hertz, N., Pisella, L.I., Buhler, E., Schaller, F., Duan, J., Khanna, A.R., Bishop, P.N., et al. (2015). WNK1-regulated inhibitory phosphorylation of the KCC2 cotransporter maintains the depolarizing action of GABA in immature neurons. Sci Signal 8, ra65. 
Fukuda, A., Tanaka, M., Yamada, Y., Muramatsu, K., Shimano, Y., and Nishino, H. (1998). Simultaneous optical imaging of intracellular $\mathrm{Cl}$ - in neurons in different layers of rat neocortical slices: advantages and limitations. Neuroscience research 32, 363-371.

Funk, K., Woitecki, A., Franjic-Wurtz, C., Gensch, T., Mohrlen, F., and Frings, S. (2008). Modulation of chloride homeostasis by inflammatory mediators in dorsal root ganglion neurons. Molecular pain 4, 32. Garand, D., Mahadevan, V., and Woodin, M.A. (2019). Ionotropic and metabotropic kainate receptor signalling regulates $\mathrm{Cl}(-)$ homeostasis and GABAergic inhibition. J Physiol 597, 1677-1690.

Gauvain, G., Chamma, I., Chevy, Q., Cabezas, C., Irinopoulou, T., Bodrug, N., Carnaud, M., Levi, S., and Poncer, J.C. (2011). The neuronal K-Cl cotransporter KCC2 influences postsynaptic AMPA receptor content and lateral diffusion in dendritic spines. Proc Natl Acad Sci U S A 108, 15474-15479.

Gensch, T., Untiet, V., Franzen, A., Kovermann, P., and Fahlke, C. (2015). Determination of Intracellular Chloride Concentrations by Fluorescence Lifetime Imaging. Advanced Time-Correlated Single Photon Counting Applications 111, 189-211.

Gilbert, D., Franjic-Wurtz, C., Funk, K., Gensch, T., Frings, S., and Mohrlen, F. (2007). Differential maturation of chloride homeostasis in primary afferent neurons of the somatosensory system.

International journal of developmental neuroscience : the official journal of the International Society for Developmental Neuroscience 25, 479-489.

Glykys, J., Dzhala, V., Egawa, K., Balena, T., Saponjian, Y., Kuchibhotla, K.V., Bacskai, B.J., Kahle, K.T., Zeuthen, T., and Staley, K.J. (2014). Local impermeant anions establish the neuronal chloride concentration. Science 343, 670-675.

Glykys, J., Dzhala, V., Egawa, K., Kahle, K.T., Delpire, E., and Staley, K. (2017). Chloride Dysregulation, Seizures, and Cerebral Edema: A Relationship with Therapeutic Potential. Trends in neurosciences 40, 276-294.

Grimley, J.S., Li, L., Wang, W., Wen, L., Beese, L.S., Hellinga, H.W., and Augustine, G.J. (2013). Visualization of synaptic inhibition with an optogenetic sensor developed by cell-free protein engineering automation. J Neurosci 33, 16297-16309.

Gulyas, A.I., Sik, A., Payne, J.A., Kaila, K., and Freund, T.F. (2001). The KCl cotransporter, KCC2, is highly expressed in the vicinity of excitatory synapses in the rat hippocampus. The European journal of neuroscience 13, 2205-2217.

Gut, G., Herrmann, M.D., and Pelkmans, L. (2018). Multiplexed protein maps link subcellular organization to cellular states. Science 361 .

Halpain, S., Hipolito, A., and Saffer, L. (1998). Regulation of F-Actin Stability in Dendritic Spines by Glutamate Receptors and Calcineurin. The Journal of Neuroscience 18, 9835-9844.

Hansen, A.J., and Nedergaard, M. (1988). Brain ion homeostasis in cerebral ischemia. Neurochemical pathology 9, 195-209.

Heubl, M., Zhang, J., Pressey, J.C., Al Awabdh, S., Renner, M., Gomez-Castro, F., Moutkine, I., Eugene, E., Russeau, M., Kahle, K.T., et al. (2017). GABAA receptor dependent synaptic inhibition rapidly tunes KCC2 activity via the Cl(-)-sensitive WNK1 kinase. Nat Commun 8, 1776.

Hyde, T.M., Lipska, B.K., Ali, T., Mathew, S.V., Law, A.J., Metitiri, O.E., Straub, R.E., Ye, T., Colantuoni, C., Herman, M.M., et al. (2011). Expression of GABA signaling molecules KCC2, NKCC1, and GAD1 in cortical development and schizophrenia. J Neurosci 31, 11088-11095.

Inoue, H., and Okada, Y. (2007). Roles of volume-sensitive chloride channel in excitotoxic neuronal injury. J Neurosci 27, 1445-1455.

Jaenisch, N., Witte, O.W., and Frahm, C. (2010). Downregulation of potassium chloride cotransporter KCC2 after transient focal cerebral ischemia. Stroke 41, e151-159.

Jun, I., Cheng, M.H., Sim, E., Jung, J., Suh, B.L., Kim, Y., Son, H., Park, K., Kim, C.H., Yoon, J.H., et al. (2016). Pore dilatation increases the bicarbonate permeability of CFTR, ANO1 and glycine receptor anion channels. J Physiol 594, 2929-2955.

Kahle, K.T., Deeb, T.Z., Puskarjov, M., Silayeva, L., Liang, B., Kaila, K., and Moss, S.J. (2013). Modulation of neuronal activity by phosphorylation of the $\mathrm{K}-\mathrm{Cl}$ cotransporter $\mathrm{KCC} 2$. Trends in neurosciences $36,726-737$. 
Kaila, K. (1994). Ionic basis of GABAA receptor channel function in the nervous system. Progress in neurobiology 42, 489-537.

Kaila, K., Price, T.J., Payne, J.A., Puskarjov, M., and Voipio, J. (2014). Cation-chloride cotransporters in neuronal development, plasticity and disease. Nature reviews Neuroscience 15, 637-654.

Kaila, K., and Voipio, J. (1987). Postsynaptic fall in intracellular pH induced by GABA-activated bicarbonate conductance. Nature 330, 163-165.

Kaila, K., Voipio, J., Paalasmaa, P., Pasternack, M., and Deisz, R.A. (1993). The role of bicarbonate in GABAA receptor-mediated IPSPs of rat neocortical neurones. J Physiol 464, 273-289.

Kaneko, H., Putzier, I., Frings, S., and Gensch, T. (2002). Determination of intracellular chloride concentration in dorsal root ganglion neurons by fluorescence lifetime imaging. Current Topics in Membranes 53, 167-189.

Kaneko, H., Putzier, I., Frings, S., Kaupp, U.B., and Gensch, T. (2004). Chloride accumulation in mammalian olfactory sensory neurons. J Neurosci 24, 7931-7938.

Kettenmann, H., and Schachner, M. (1985). Pharmacological properties of gamma-aminobutyric acid-, glutamate-, and aspartate-induced depolarizations in cultured astrocytes. J Neurosci 5, 3295-3301. Khirug, S., Yamada, J., Afzalov, R., Voipio, J., Khiroug, L., and Kaila, K. (2008). GABAergic depolarization of the axon initial segment in cortical principal neurons is caused by the $\mathrm{Na}-\mathrm{K}-2 \mathrm{Cl}$ cotransporter NKCC1. J Neurosci 28, 4635-4639.

Koncz, C., and Daugirdas, J. (1994). Use of MQAE for measurement of intracellular [Cl-] in cultured aortic smooth muscle cells. American Journal of Physiology Dec, H2114-2123.

Kovalchuk, Y., and Garaschuk, O. (2012). Two-photon chloride imaging using MQAE in vitro and in vivo. Cold Spring Harbor protocols 2012, 778-785.

Kuner, T., and Augustine, G.J. (2000). A genetically encoded ratiometric indicator for chloride: capturing chloride transients in cultured hippocampal neurons. Neuron 27, 447-459.

Kwon, T., Sakamoto, M., Peterka, D.S., and Yuste, R. (2017). Attenuation of Synaptic Potentials in Dendritic Spines. Cell reports 20,1100-1110.

Lipton, P. (1999). Ischemic cell death in brain neurons. Physiol Rev 79, 1431-1568.

Lloyd, W.R., Wilson, R.H., Chang, C.W., Gillispie, G.D., and Mycek, M.A. (2010). Instrumentation to rapidly acquire fluorescence wavelength-time matrices of biological tissues. Biomed Opt Express 1, 574586.

Lombardi, A., Jedlicka, P., Luhmann, H.J., and Kilb, W. (2019). Interactions between Membrane Resistance, GABA-A Receptor Properties, Bicarbonate Dynamics and Cl(-)-Transport Shape ActivityDependent Changes of Intracellular Cl(-) Concentration. Int J Mol Sci 20.

MacVicar, B.A., Tse, F.W., Crichton, S.A., and Kettenmann, H. (1989). GABA-activated Cl- channels in astrocytes of hippocampal slices. J Neurosci 9, 3577-3583.

Marandi, N., Konnerth, A., and Garaschuk, O. (2002). Two-photon chloride imaging in neurons of brain slices. Pflugers Archiv : European journal of physiology 445, 357-365.

Mohapatra, N., Tonnesen, J., Vlachos, A., Kuner, T., Deller, T., Nagerl, U.V., Santamaria, F., and Jedlicka, P. (2016). Spines slow down dendritic chloride diffusion and affect short-term ionic plasticity of GABAergic inhibition. Sci Rep 6, 23196.

Moore, Y.E., Conway, L.C., Wobst, H.J., Brandon, N.J., Deeb, T.Z., and Moss, S.J. (2019).

Developmental Regulation of KCC2 Phosphorylation Has Long-Term Impacts on Cognitive Function. Frontiers in molecular neuroscience 12, 173.

Moore, Y.E., Deeb, T.Z., Chadchankar, H., Brandon, N.J., and Moss, S.J. (2018). Potentiating KCC2 activity is sufficient to limit the onset and severity of seizures. Proc Natl Acad Sci U S A 115, 1016610171.

Mukhtarov, M., Liguori, L., Waseem, T., Rocca, F., Buldakova, S., Arosio, D., and Bregestovski, P. (2013). Calibration and functional analysis of three genetically encoded $\mathrm{Cl}(-) / \mathrm{pH}$ sensors. Frontiers in molecular neuroscience 6,9 . 
Murphy, T.H., Li, P., Betts, K., and Liu, R. (2008). Two-photon imaging of stroke onset in vivo reveals that NMDA-receptor independent ischemic depolarization is the major cause of rapid reversible damage to dendrites and spines. J Neurosci 28, 1756-1772.

Nicoll, R.A., Padjen, A., and Barker, J.L. (1976). Analysis of amino acid responses on frog motoneurones. Neuropharmacology 15, 45-53.

Oheim, M., Beaurepaire, E., Chaigneau, E., Mertz, J., and Charpak, S. (2001). Two-photon microscopy in brain tissue: parameters influencing the imaging depth. Journal of neuroscience methods 111, 29-37. Payne, J.A. (1997). Functional characterization of the neuronal-specific K-Cl cotransporter: implications for $[\mathrm{K}+]$ o regulation. The American journal of physiology 273, C1516-1525.

Pisella, L.I., Gaiarsa, J.L., Diabira, D., Zhang, J., Khalilov, I., Duan, J., Kahle, K.T., and Medina, I. (2019). Impaired regulation of KCC2 phosphorylation leads to neuronal network dysfunction and neurodevelopmental pathology. Sci Signal 12.

Pond, B.B., Berglund, K., Kuner, T., Feng, G., Augustine, G.J., and Schwartz-Bloom, R.D. (2006). The chloride transporter $\mathrm{Na}(+)-\mathrm{K}(+)-\mathrm{Cl}$ - cotransporter isoform-1 contributes to intracellular chloride increases after in vitro ischemia. J Neurosci 26, 1396-1406.

Rial Verde, E.M., Zayat, L., Etchenique, R., and Yuste, R. (2008). Photorelease of GABA with Visible Light Using an Inorganic Caging Group. Frontiers in neural circuits 2, 2. Rinehart, J., Maksimova, Y.D., Tanis, J.E., Stone, K.L., Hodson, C.A., Zhang, J., Risinger, M., Pan, W., Wu, D., Colangelo, C.M., et al. (2009). Sites of regulated phosphorylation that control K-Cl cotransporter activity. Cell 138, 525-536.

Rossi, D.J., Brady, J.D., and Mohr, C. (2007). Astrocyte metabolism and signaling during brain ischemia. Nature neuroscience 10, 1377-1386.

Rothman, S.M. (1985). The neurotoxicity of excitatory amino acids is produced by passive chloride influx. J Neurosci 5, 1483-1489.

Rungta, R.L., Choi, H.B., Tyson, J.R., Malik, A., Dissing-Olesen, L., Lin, P.J.C., Cain, S.M., Cullis, P.R., Snutch, T.P., and MacVicar, B.A. (2015). The cellular mechanisms of neuronal swelling underlying cytotoxic edema. Cell 161, 610-621.

Silayeva, L., Deeb, T.Z., Hines, R.M., Kelley, M.R., Munoz, M.B., Lee, H.H., Brandon, N.J., Dunlop, J., Maguire, J., Davies, P.A., et al. (2015). KCC2 activity is critical in limiting the onset and severity of status epilepticus. Proc Natl Acad Sci U S A 112, 3523-3528.

Staley, K.J., and Proctor, W.R. (1999). Modulation of mammalian dendritic GABA(A) receptor function by the kinetics of Cl- and HCO3- transport. J Physiol 519 Pt 3, 693-712.

Steffensen, A.B., Sword, J., Croom, D., Kirov, S.A., and MacAulay, N. (2015). Chloride Cotransporters as a Molecular Mechanism underlying Spreading Depolarization-Induced Dendritic Beading. J Neurosci 35, 12172-12187.

Su, G., Kintner, D.B., Flagella, M., Shull, G.E., and Sun, D. (2002). Astrocytes from Na(+)-K(+)-Cl(-) cotransporter-null mice exhibit absence of swelling and decrease in EAA release. Am J Physiol Cell Physiol 282, C1147-1160.

Sulis Sato, S., Artoni, P., Landi, S., Cozzolino, O., Parra, R., Pracucci, E., Trovato, F., Szczurkowska, J., Luin, S., Arosio, D., et al. (2017). Simultaneous two-photon imaging of intracellular chloride concentration and $\mathrm{pH}$ in mouse pyramidal neurons in vivo. Proc Natl Acad Sci U S A 114, E8770-E8779. Tao, R., Li, C., Newburn, E.N., Ye, T., Lipska, B.K., Herman, M.M., Weinberger, D.R., Kleinman, J.E., and Hyde, T.M. (2012). Transcript-specific associations of SLC12A5 (KCC2) in human prefrontal cortex with development, schizophrenia, and affective disorders. J Neurosci 32, 5216-5222.

Thompson, R.J., Jackson, M.F., Olah, M.E., Rungta, R.L., Hines, D.J., Beazely, M.A., MacDonald, J.F., and MacVicar, B.A. (2008). Activation of pannexin-1 hemichannels augments aberrant bursting in the hippocampus. Science 322, 1555-1559.

Tsien, R.Y. (1998). The green fluorescent protein. Annual review of biochemistry 67, 509-544. Untiet, V., Kovermann, P., Gerkau, N.J., Gensch, T., Rose, C.R., and Fahlke, C. (2017). Glutamate transporter-associated anion channels adjust intracellular chloride concentrations during glial maturation. Glia 65, 388-400. 
Untiet, V., Moeller, L.M., Ibarra-Soria, X., Sanchez-Andrade, G., Stricker, M., Neuhaus, E.M., Logan, D.W., Gensch, T., and Spehr, M. (2016). Elevated Cytosolic Cl- Concentrations in Dendritic Knobs of Mouse Vomeronasal Sensory Neurons. Chemical senses 41, 669-676.

Verkman, A.S., Sellers, M.C., Chao, A.C., Leung, T., and Ketcham, R. (1989). Synthesis and characterization of improved chloride-sensitive fluorescent indicators for biological applications. Analytical biochemistry 178, 355-361.

Watanabe, M., Zhang, J., Mansuri, M.S., Duan, J., Karimy, J.K., Delpire, E., Alper, S.L., Lifton, R.P., Fukuda, A., and Kahle, K.T. (2019). Developmentally regulated KCC2 phosphorylation is essential for dynamic GABA-mediated inhibition and survival. Sci Signal 12.

Weilinger, N.L., Lohman, A.W., Rakai, B.D., Ma, E.M., Bialecki, J., Maslieieva, V., Rilea, T., Bandet, M.V., Ikuta, N.T., Scott, L., et al. (2016). Metabotropic NMDA receptor signaling couples Src family kinases to pannexin-1 during excitotoxicity. Nature neuroscience 19, 432-442.

Weilinger, N.L., Tang, P.L., and Thompson, R.J. (2012). Anoxia-induced NMDA receptor activation opens pannexin channels via Src family kinases. J Neurosci 32, 12579-12588.

Williams, J.R., and Payne, J.A. (2004). Cation transport by the neuronal $\mathrm{K}(+)-\mathrm{Cl}(-)$ cotransporter $\mathrm{KCC} 2$ : thermodynamics and kinetics of alternate transport modes. Am J Physiol Cell Physiol 287, C919-931.

Williams, J.R., Sharp, J.W., Kumari, V.G., Wilson, M., and Payne, J.A. (1999). The neuron-specific K-Cl cotransporter, KCC2. Antibody development and initial characterization of the protein. J Biol Chem 274, 12656-12664.

Williams, S.R., and Mitchell, S.J. (2008). Direct measurement of somatic voltage clamp errors in central neurons. Nature neuroscience 11, 790-798.

Yuste, R., and Denk, W. (1995). Dendritic spines as basic functional units of neuronal integration. Nature $375,682-684$.

Zhou, H.Y., Chen, S.R., Byun, H.S., Chen, H., Li, L., Han, H.D., Lopez-Berestein, G., Sood, A.K., and Pan, H.L. (2012). N-methyl-D-aspartate receptor- and calpain-mediated proteolytic cleavage of K+-Clcotransporter-2 impairs spinal chloride homeostasis in neuropathic pain. J Biol Chem 287, 33853-33864. 